\title{
Summer distribution of micro- and small meso- zooplankton in the Red Sea and Gulf of Aden, with special reference to non-calanoid copepods
}

\author{
Ruth Böttger-Schnack \\ Institut für Meereskunde an der Universität Kiel, Düsternbrooker Weg 20, D-24105 Kiel, Germany
}

\begin{abstract}
From the Gulf of Aden along a transect to the central-northern Red Sea the abundance and taxonomic composition of metazoan plankton was studied during the southwest monsoon period (summer 1987). Samples were taken with $0.055 \mathrm{~mm}$ mesh nets down to a maximum depth of $1050 \mathrm{~m}$. In the epipelagic zone, a distinct decrease in total plankton abundance was observed from south to north, which was much more pronounced in biomass (by a factor of up to 10) as compared to numbers (by a factor of 2). This could partly be explained by differences in the taxonomic and/or size composition of the planktonic fauna. Among non-calanoid copepods, 40 out of 75 species or taxa investigated decreased in abundance from south to north. Sixteen of these species were completely absent in the central-northern area. Nineteen species or taxa, however, showed the opposite feature of a higher abundance in the central-northern Red Sea. The stations were grouped according to similarities in the taxonomic composition of non-calanoid copepods in the epipelagic zone. The following 3 geographical regions could be separated: (1) Gulf of Aden and Strait of Bab al Mandab; (2) southern Red Sea; and (3) central-northern Red Sea. In the meso- and bathypelagic zones, regional differences were not evident. The results are discussed in relation to hydrographic conditions during summer 1987.
\end{abstract}

KEY WORDS: Small mesozooplankton $\cdot$ Red Sea $\cdot$ South-north differences Vertical distribution Noncalanoid copepods . Oncaea

\section{INTRODUCTION}

Micrometazoans smaller than $1 \mathrm{~mm}$ in size form a group of organisms that has only rarely been considered in studies on oceanic zooplankton communities. Böttger $(1985,1987)$ reviewed the earlier literature, and few studies have been added in subsequent years (Roman et al. 1985, Cowles et al. 1987). The ecological importance of this size fraction as potential prey for adult and larval fish (e.g. Arthur 1977, Govoni et al. 1986, Kellermann 1990, Kinzer et al. 1993) and larger invertebrates (e.g. Kimmerer 1984) is well known and it is only recently that their importance for the grazing impact on phytoplankton has been pointed out (Morales et al. 1991, 1993).

Copepods form the most important taxon among pelagic oceanic micrometazoans. In this size category, they are not only represented by numerous developmental stages, but also by a great number of extremely small species. In samples of larger mesh sizes, calanoid copepods usually dominate in variety as well as in total biomass and number (e.g. Weikert 1982, Beckmann 1984). In small mesh net samples, however, noncalanoid taxa have been found to be the most important group at least by numbers (Gordeyeva 1970, Star \& Mullin 1981, Böttger 1985, 1987, Cowles et al. 1987). The relative importance of these non-calanoids has been found to increase strongly with increasing depth (Böttger 1985, 1987). This is mainly due to the poecilostomatoid genus Oncaea that contains a great number of very small mesopelagic species (Böttger-Schnack $1990 a, b)$. The numerical dominance of Oncaea in meso- and bathypelagic zones seems to be a typical feature for tropical/subtropical areas (Böttger-Schnack 1994), but has also been observed in other regions (Schnack et al. 1985, Metz 1993).

In the Red Sea, recent studies with $0.1 \mathrm{~mm}$ mesh nets have given first insights into the taxonomic composi- 
tion and vertical distribution patterns of cyclopoid and poecilostomatoid copepod species in the central and northern area (Böttger-Schnack 1988, 1990a, b, 1992, Bötger-Schnack et al. 1989). These studies were restricted to the upper $450 \mathrm{~m}$ and to the autumn and winter (northwest monsoon) periods. Methodologically important was the result that adults of the smallest Oncaea species, which are in the size range 0.2 to $0.3 \mathrm{~mm}$, could not be sampled quantitatively even with nets of $0.1 \mathrm{~mm}$ mesh size (Böttger 1985). Seasonal differences in the results on the taxonomic composition of cyclopoids and poecilostomatoids in the central Red Sea (Böttger-Schnack 1990b) were difficult to interpret due to a lack of corresponding data from the southern Red Sea. It is known that the species composition in the central area is influenced by an inflow of plankton species from the Gulf of Aden during winter and spring (Halim 1969, Weikert 1980, 1987). Compared to results for the calanoid fauna in the central Red Sea (Weikert 1982), non-calanoids showed a less-pronounced dominance of single species in the upper mesopelagic zone (Böttger-Schnack 1988). Whether this difference can also be observed further down in the water column is not known, as corresponding investigations in the lower meso- and bathypelagic zones are lacking

According to its productivity, the Red Sea has been divided latitudinally into 2 main subregions, whose limits are located at about $18^{\circ} \mathrm{N}$ (Weikert 1987, 1988a). The northern part is less productive and has a less diverse fauna than the southern part, whose surface layers are influenced by a regular inflow of nutrients and planktonic organisms from the Gulf of Aden. The system is depending on the monsoon-driven water exchange through the shallow Strait of Bab al Mandab (Halim 1969, 1984, Morcos 1970, Kimor 1973). During winter (October to May), surface water from the Gulf of Aden flows northwards into the Red Sea. This is compensated for by an outflow of Red Sea water at greater depth (Siedler 1968, Morcos 1970, Edwards 1987). During summer (late June to early October), the wind direction over the southern part of the Red Sea is reversed and the 2 existing layers at $\mathrm{Bab}$ al Mandab are superimposed by a surface current flowing southwards from the Red Sea into the Gulf (Morcos 1970 , Maillard \& Soliman 1986).

A great number of taxonomic and zoogeographical. observations have been reported on the invasion and northern extension of Gulf zooplankton into the Red Sea (see Halim 1969 and Weikert 1987 for a review of the literature), but only limited quantitative information is available on the abundance and community structure of southern Red Sea plankton as it is effected by the water exchange with the Gulf of Aden. Mostly, the studies were conducted during winter and spring, when the inflow from the Gulf is greatest (Delalo 1966 ,
Beckmann 1984, unpubl.). For the summer season, only a few data on zooplankton abundance are available from the southern Red Sea (Rudyakov \& Voronina 1967, Ponomareva 1968). All these data are based on samples with nets of 0.2 or $0.3 \mathrm{~mm}$ mesh size, which cannot sample quantitatively the numerous small metazoans.

The present study addresses this specific gap in the knowledge about Red Sea plankton and reports on the abundance and taxonomic composition of the small metazoan plankton caught with nets of $0.055 \mathrm{~mm}$ mesh size. The samples were taken in summer 1987 during the southwest monsoon period along a transect from the Gulf of Aden to the central and northern Red Sea $\left(23^{\circ} \mathrm{N}\right)$ down to a maximum depth of $1050 \mathrm{~m}$. Special attention is given to the species abundances and vertical distributions of non-calanoid copepods, in order to supplement the present knowledge which is mainly restricted to calanoids in the southern parts of the Red Sea. For the central Red Sea, the new results from summer are compared with published data from other seasons to provide further information on seasonal variation in the abundance of medium-sized non-calanoids in this area.

\section{MATERIAL AND METHODS}

During RV 'Meteor' Cruise 5 (MINDIK) zooplankton samples were collected between July 11 and August 6, 1987, on a transect from the Gulf of Aden to the northern Red Sea (Fig. 1). Maximum sampling depth was $1050 \mathrm{~m}$. The research work was conducted in territorial waters of the Sudan, North Yemen and Djibouti; investigations in the northern Red Sea beyond Sudanese territorial waters were not permitted (Weikert 1988b). A total of 23 sampling series (Table 1) were grouped geographically into 5 different regions (Fig. 1): A, Gulf of Aden; B, Bab al Mandab; C, southern Red Sea; D. Central Red Sea; and E, northern Red Sea. Samples were taken of vertical hauls during day and night with a multiple opening-closing plankton net. The sampler had a mouth area of $0.25 \mathrm{~m}^{2}$ (Weikert \& John 1981), and was equipped with 5 nets of $0.055 \mathrm{~mm}$ mesh size. The depth of the nets was determined by a pressure recorder; the limits of the depth strata sampled varied only a few meters from preset values. The sampled depth ranges were generally resolved by $50 \mathrm{~m}$ steps down to $450 \mathrm{~m}$ and by $150 \mathrm{~m}$ steps between 450 and $1050 \mathrm{~m}$. Total ranges of $250 \mathrm{~m}$ or less were taken by $20 \mathrm{~m}$ steps in the upper $100 \mathrm{~m}$ and by 25 or $50 \mathrm{~m}$ steps below $100 \mathrm{~m}$. In the Gulf of Aden, 2 sampling series from the upper $250 \mathrm{~m}$ were resolved by $50 \mathrm{~m}$ steps only. No clogging of the net was observed; assuming a filtration efficiency of $100 \%$, 


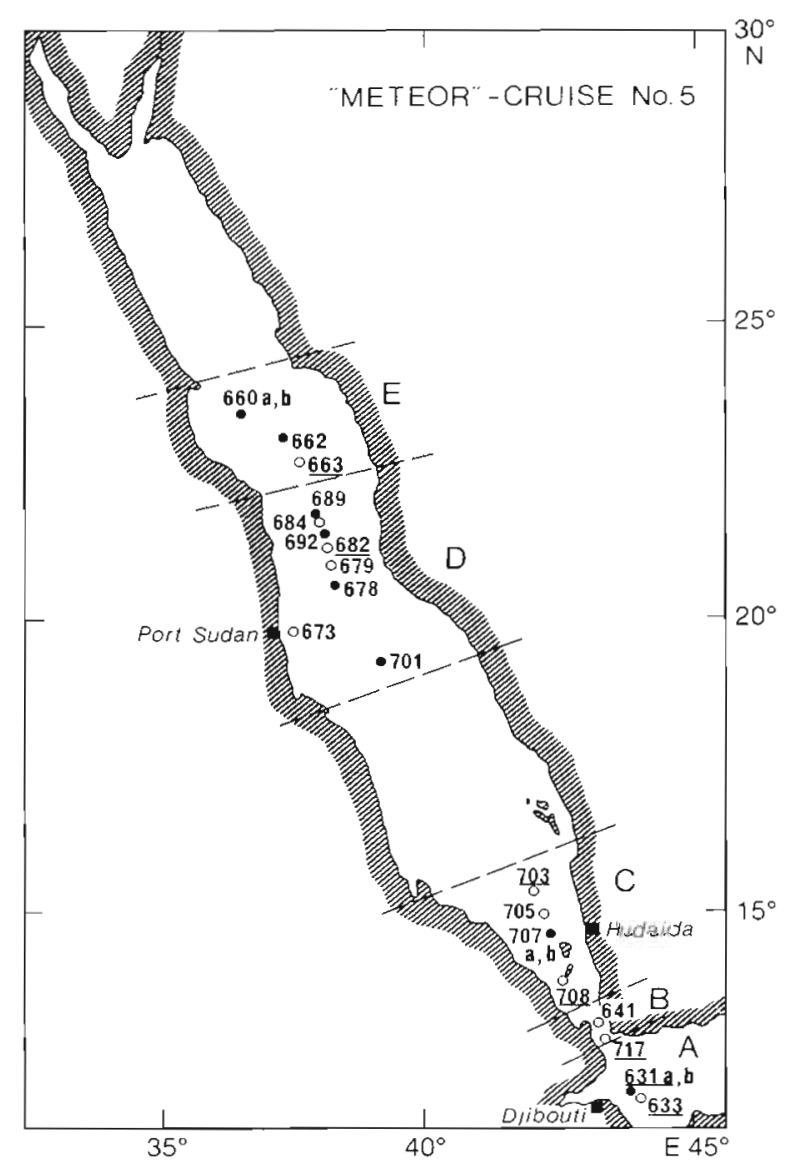

Fig. 1. Plankton sampling stations in the Red Sea and Gulf of Aden during summer 1987. (ㅇ) Daytime samples; $(\bullet)$ nighttime samples. A: Gulf of Aden; B: Bab al Mandab; C: southern Red Sea; D: central Red Sea; E: northern Red Sea. Those 7 stations which were selected for a detailed analysis of zooplankton abundance and taxonomic composition are underlined

the volumes filtered ranged between $5 \mathrm{~m}^{3}$ (20 m intervals) and $37.5 \mathrm{~m}^{3}$ (150 $\mathrm{m}$ intervals). Plankton samples were fixed in a $4 \%$ formaldehyde-seawater solution buffered with hexamethylene tetramine $(2 \%$ by weight). For sorting and further storage the plankton samples were transferred into a preservation fluid containing $5 \%$ propylene glycol, $0.5 \%$ propylene phenoxetol and $94.5 \%$ filtered seawater (Steedman 1976) after 2 yr of fixation.

Total plankton biomass, including phytoplankton and detritus, was determined for all samples from 23 series by wet weight as described by Böttger (1982). Individual large organisms $(>1 \mathrm{~cm})$, mostly fishes or large crustaceans, were weighed separately and have not been included in the present evaluation. For 2 surface samples in the central Red Sea (Stn 682: 0-50 m; Stn 692: $0-20 \mathrm{~m}$ ) only the larger plankton fraction (>0.3 mm) was weighed, because large amounts of gelatinous material clogged the fine gauze filters. Fila- mentous cyanobacteria (Trichodesmium spp.) occurred regularly in the samples, but no bloom conditions were encountered (see Böttger-Schnack 1991 for details). In the northern Red Sea (Stns 662 and 663) large numbers of diatoms (Rhizosolenia spp.), which were infected by the endosymbiontic cyanobacteria Richelia intracellularis, and dinoflagellates were noted in the surface samples. No phytoplankton correction was employed on the biomass data. Based on earlier observations (Böttger 1987), the share of phytoplankton in the total plankton biomass was assumed to be low in $0.05 \mathrm{~mm}$ mesh net samples.

For numerical abundance and taxonomic composition of the zooplankton, including the species abundance of non-calanoid copepods, the samples of 7 series have been evaluated, 1 at least from each of the 5 regions (Table 1, Fig. 1). Except for the Gulf of Aden, only daytime samples were enumerated in order to eliminate differences due to diurnal vertical migration. In the central-northern Red Sea (Regions D and E), 2 sampling series down to $1050 \mathrm{~m}$ were enumerated (Stns 663 and 682); in the southern Red Sea (Region C) 1 deep series down to $1050 \mathrm{~m}$ from the oceanic area (Stn 703), and 1 shallow series from the neritic area was evaluated (Stn 708, Fig. 1). In the Strait of Bab al Mandab, at the southern entrance of the Red Sea, samples from August (Stn 717) were chosen. In the Gulf of Aden, daytime series covered the upper $100 \mathrm{~m}$ only. To enlarge the considered vertical range for this region, 1 nighttime series down to $250 \mathrm{~m}$ was enumerated (Stn 631a) in addition to 1 daytime series (Stn 633).

For numerical analysis, samples were divided into 2 size fractions by filtration through $0.3 \mathrm{~mm}$ mesh gauze. In the larger fraction usually all organisms were counted. For abundant smaller organisms only subsamples of ca 500 to 1500 individuals were enumerated. Subsamples of the smaller size fraction were taken with a 4-quarter splitter as described by Böttger (1985). Replicate counts showed no significant differences between the 4 quarters of the splitter (chisquared test, $\mathrm{p}<0.05$ ). Some medium-sized copepod species, which were present in both fractions (e.g. Farranula spp.), as well as less abundant small species were counted from the total samples. The quantitative analysis was made under a stereomicroscope at a magnification of $25 \times$ or $75 \times$. Metazoan plankters were identified to major taxonomic groups (usually orders); among the Copepoda, nauplii and copepodids were counted separately. Empty copepod exoskeletons as well as specimens that showed an advanced degree of internal disintegration (carcasses) were distinguished according to the criteria given by Wheeler (1967), Weikert (1977) and Böttger-Schnack (1990a) and were counted separately. 
Table 1. Station list for sampling conducted in 1987. 'Series selected for evaluation of metazoan abundance and composition D: day; N: night; -: no plankton sampling; $H$ : hydrographic profiles taken

\begin{tabular}{|c|c|c|c|c|c|c|}
\hline Stn & Date & Time & $\begin{array}{l}\text { Plankton sampling } \\
\text { depth (m) }\end{array}$ & $\begin{array}{c}\text { Hydrographic } \\
\text { profile? }\end{array}$ & $\begin{array}{l}\text { Total water } \\
\text { depth }(\mathrm{m})\end{array}$ & $\begin{array}{c}\text { Geographic } \\
\text { position }\left({ }^{\circ} \mathrm{N},{ }^{\circ} \mathrm{E}\right)\end{array}$ \\
\hline 628 & Jul 10 & - & - & $\mathrm{H}$ & 1340 & $12^{\circ} 42.2^{\prime}, 48^{\circ} 27.2^{\prime}$ \\
\hline$\cdot 631 a$ & Jul 11 & $N$ & $0-250$ & & 1400 & $11^{\circ} 55.5^{\prime}, 43^{\circ} 37.9^{\prime}$ \\
\hline $631 \mathrm{~b}$ & Jul 11 & $N$ & $0-250$ & & 1240 & \\
\hline$\cdot 633$ & Jul 11 & $\mathrm{D}$ & $0-100$ & & 1330 & $11^{\circ} 56.9^{\prime}, 43^{\circ} 46.8^{\prime}$ \\
\hline 641 & Jul 12 & $\mathrm{D}$ & $0-220$ & & 245 & $12^{\circ} 39.5^{\prime}, 42^{\circ} 14.5^{\prime}$ \\
\hline $660 a$ & Jul 18 & $N$ & $0-1050$ & & 1300 & $23^{\circ} 396^{\prime}, 36^{\circ} 36.8^{\prime}$ \\
\hline $660 \mathrm{~b}$ & Jul 18 & N & $0-100$ & & 1200 & \\
\hline 662 & Jul 20 & $\mathrm{~N}$ & $0-1050$ & & 2200 & $23^{\circ} 06.1^{\prime}, 37^{\circ} 14.7^{\prime}$ \\
\hline$\cdot 663$ & Jul 20 & $\mathrm{D}$ & $0-1050$ & $\mathrm{H}$ & 1200 & $22^{\circ} 58.4^{\prime}, 37^{\circ} 19,4^{\prime}$ \\
\hline 673 & Jul 22 & $\mathrm{D}$ & $0-450$ & & 690 & $19^{\circ} 43.8^{\prime}, 37^{\circ} 29.1^{\prime}$ \\
\hline 678 & Jul 24 & $\mathrm{~N}$ & $0-1050$ & & 2100 & $20^{\circ} 39.0^{\prime}, 38^{\circ} 12.5^{\prime}$ \\
\hline 679 & Jul 24 & $\mathrm{D}$ & $0-450$ & & 1950 & $20^{\circ} 58.9^{\prime}, 38^{\circ} 066^{\prime}$ \\
\hline .682 & Jul 25 & $\mathrm{D}$ & $0-1050$ & & 1890 & $21^{\circ} 13.9^{\prime}, 38^{\circ} 05.7^{\prime}$ \\
\hline 684 & Jul 26 & $\mathrm{D}$ & $0-100$ & & 2000 & $21^{\circ} 24.9^{\prime}, 38^{\circ} 02,7^{\prime}$ \\
\hline 689 & Jul 27 & $\mathrm{~N}$ & $0-1050$ & & 1350 & $21^{\circ} 27.4^{\prime}, 37^{\circ} 57.7^{\prime}$ \\
\hline 692 & Jul 27 & $\mathrm{~N}$ & $0-100$ & & 1860 & $21^{\circ} 19.2^{\prime}, 38^{\circ} 06.1^{\prime}$ \\
\hline 699 & Jul 30 & - & - & $\mathrm{H}$ & 1200 & $19^{\circ} 00.0^{\prime}, 39^{\circ} 13.1^{\prime}$ \\
\hline 701 & Jul 30 & $\mathrm{~N}$ & $0-1050$ & & 1200 & $19^{\circ} 02.6^{\prime}, 39^{\circ} 06.8^{\prime}$ \\
\hline$\cdot 703$ & Aug 3 & $\mathrm{D}$ & $0-950$ & $\mathrm{H}$ & 970 & $15^{\circ} 34.8^{\prime}, 41^{\circ} 54.9^{\prime}$ \\
\hline 705 & Aug 4 & $\mathrm{D}$ & $0-450$ & & 530 & $14^{\circ} 56.0^{\prime}, 42^{\circ} 00.2^{\prime}$ \\
\hline $707 a$ & Aug 5 & $N$ & $0-250$ & & 280 & $14^{\circ} 20.6^{\prime}, 42^{\circ} 23.1^{\prime}$ \\
\hline $707 \mathrm{~b}$ & Aug 5 & $\mathrm{~N}$ & $0-250$ & & 280 & \\
\hline .708 & Aug 5 & $\mathrm{D}$ & $0-175$ & $\mathrm{H}$ & 190 & $13^{\circ} 40.0^{\prime}, 42^{\circ} 37.4^{\prime}$ \\
\hline$\cdot 717$ & Aug 6 & $\mathrm{D}$ & $0-245$ & $\mathrm{H}$ & 250 & $12^{\circ} 32.0^{\prime}, 43^{\circ} 24.5^{\prime}$ \\
\hline
\end{tabular}

Copepodids were generally separated into the 6 suborders (Calanoida, Cyclopoida, Poecilostomatoida, Harpacticoida, Siphonostomatoida and Mormonilloida) following the scheme of Huys \& Boxshall (1991). A more detailed taxonomic analysis was carried out for the 5 non-calanoid suborders, which were identified to genera, subgenera and in most cases to species. Females and males were always counted separately and in some cases late juveniles were separated as well. Of the Oithonidae (Cyclopoida) only the 3 smallest species, Oithona nana, O. simplex and Paroithona spp. were counted. It is assumed that most sampled specimens of Paroithona belong to $P$. pacifica. However, in view of the identification problems (Ferrari \& Böttger 1986) only the genus is given in this case. Among the corycaeids, a selection of 9 species, belonging to the genera Agetus, Corycaeus, Farranula, and Urocorycaeus were included in the regional comparison. Several unidentified species beonging to the genera Onychocorycaeus and Ditrichocorycaeus, as well as unidentified juveniles of all 6 genera were grouped under 'Corycaeidae spp.' The group of unidentified sapphirinids and oncaeids, on the other hand, consisted mainly of unidentified juveniles of the given species. The identification of Oncaea tregoubovi at the southernmost stations (Stns 631,633,708 and 717) remained uncertain, because the characteristic stout median furcal setae were broken in all cases.
Environmental data that were determined at the time of the plankton sampling (Table 1), were taken from a data report by Verch et al. (1989a, b). Temperature and salinity profiles were taken with a Multisonde (ME, Kiel, Germany), and dissolved oxygen was determined from water samples by the Winkler method.

\section{RESULTS}

\section{Environmental data}

For each of the 5 regions, a typical vertical profile of temperature, salinity and dissolved oxygen is provided in Fig. 2. The surface layer always had a warmer temperature and a lower salinity than the deeper water. Surface temperatures ranged between 29 and $33^{\circ} \mathrm{C}$; sharp temperature gradients occurred between 30 to $60 \mathrm{~m}$ in the central-northern Red Sea, and even shalIower, at ca $20 \mathrm{~m}$, in the southern area. Surface salinity decreased from 39.5 pt in the central-northern Red Sea to $37.5 \mathrm{ppt}$ in the south and consequently the halocline, situated between 50 and $100 \mathrm{~m}$, became considerably stronger from north to south. Beneath $200 \mathrm{~m}$, the homogeneous deep water is found in the Red Sea, which is characterized by its constant and relatively high temperature $\left(21.6^{\circ} \mathrm{C}\right)$ and salinity $(40.5 \mathrm{ppt})$. 
A $(\operatorname{Stn} 628)$

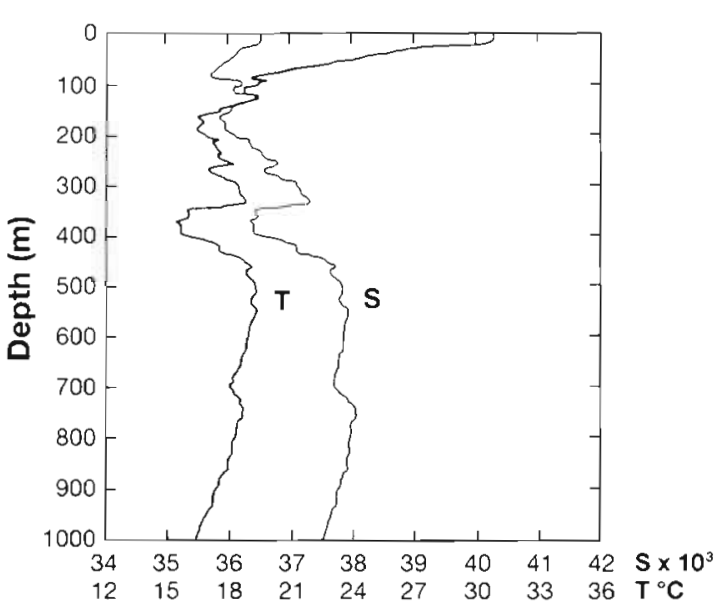

C1 (Stn 708)

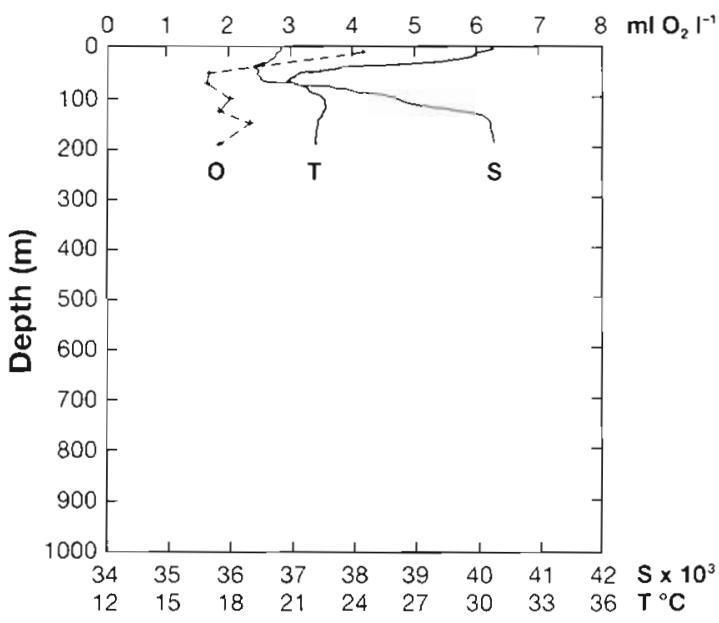

D (Stn 699)

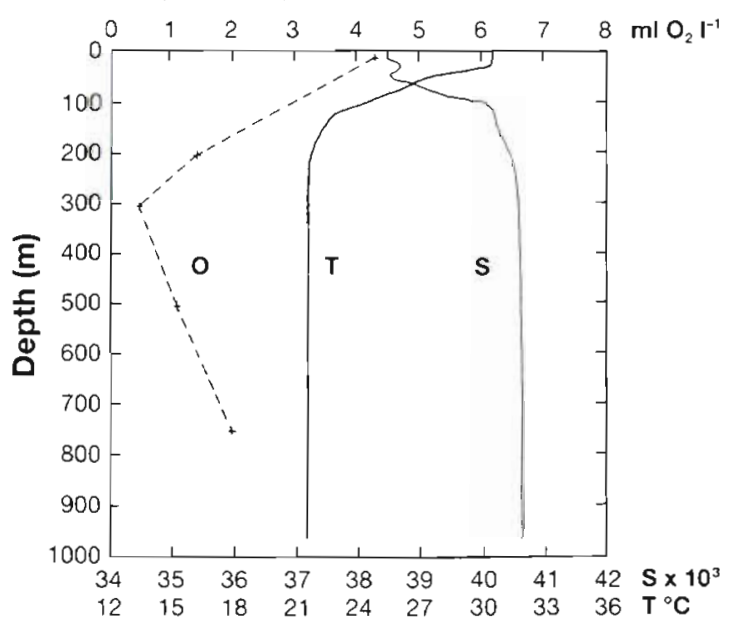

B $(\operatorname{Stn} 717)$

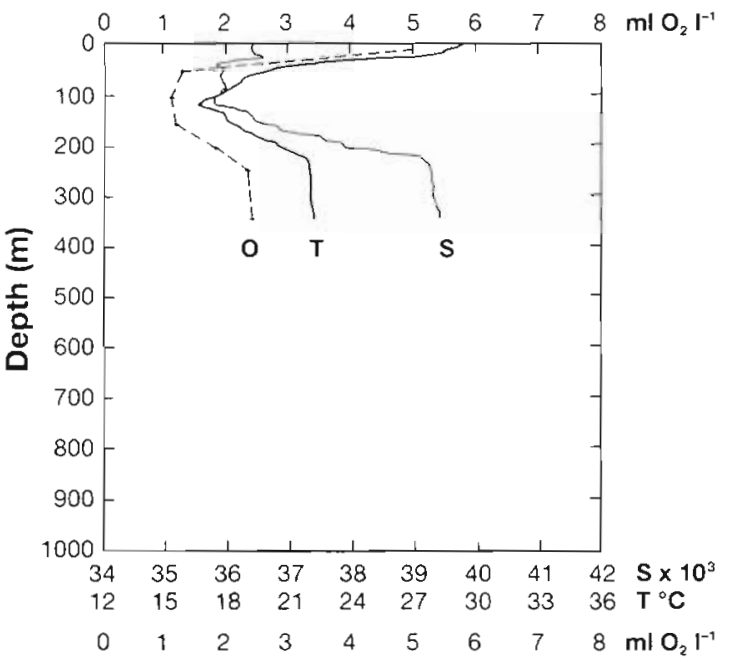

C2 (Stn 703)

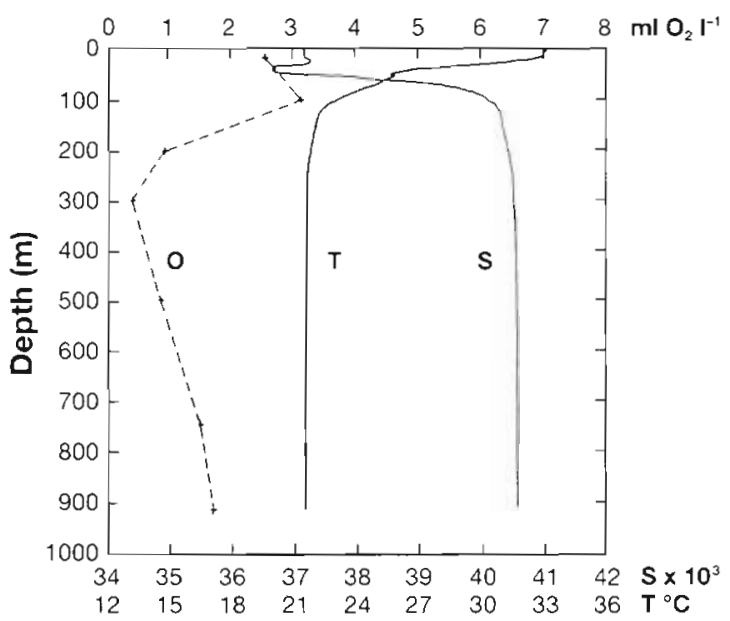

E $(\operatorname{Stn} 663)$

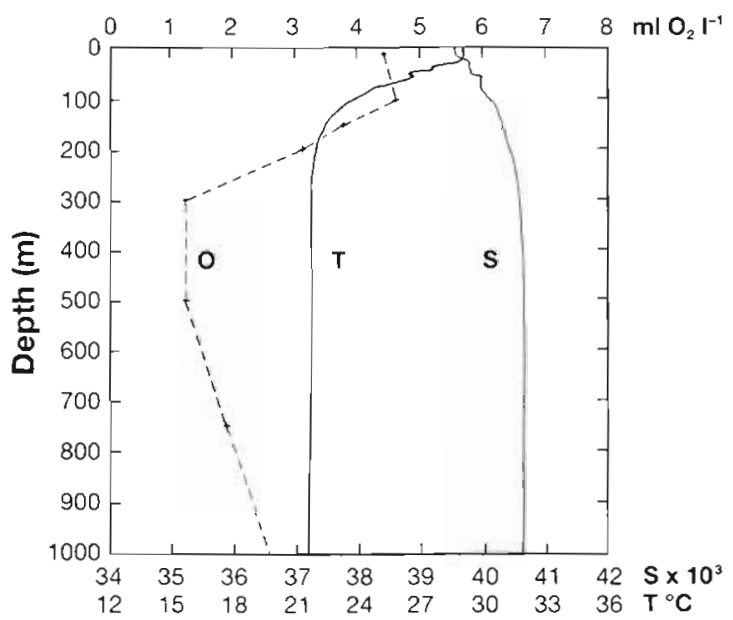

Fig 2. Vertical profiles of temperature (T), salinity (S, in ppt) and dissolved oxygen (O) in the 5 regions. A: Gulf of $A d e n ; B: B a b$ al Mandab; C: southern Red Sea (C1: shallow; C2: deep); D: central Red Sea; E: northern Red Sea 
At Bab al Mandab, a thin, warm surface layer with a temperature of $30^{\circ} \mathrm{C}$ and a salinity of $36.5 \mathrm{ppt}$ lay on top of cooler and less saline water at 60 to $180 \mathrm{~m}$ depth during both sampling dates in July and August (Fig. 2). Beneath was the deep water of the Red Sea, which is characterized by constant temperature and salinity (see above). Current velocity profiles pointed out an inflow of stratified Gulf waters at the surface, which is compensated for by outflowing Red Sea waters at greater depths (E. Mittelstaedt pers. comm.; see also Weikert 1988b). In the Gulf of Aden, the thermocline extended from 25 to $90 \mathrm{~m}$; salinity at the surface was similar to that in the Strait of Bab al Mandab (36.5 ppt) and increased gradually with depth to ca $38 \mathrm{ppt}$ below $500 \mathrm{~m}$ (Fig. 2)

Dissolved oxygen concentrations in the surface zone were high (4 to $5 \mathrm{ml} \mathrm{O}_{2} \mathrm{l}^{-1}$ ) and decreased sharply below $100 \mathrm{~m}$ depth. Minimum values of $<1.5 \mathrm{ml} \mathrm{O}_{2} \mathrm{l}^{-1}$ were found between 200 and $600 \mathrm{~m}$ depth in the northern and central Red Sea and even shallower, at ca $100 \mathrm{~m}$, in the southern area (Fig. 2). At Bab al Mandab minimum oxygen concentrations occurred between 30 and $180 \mathrm{~m}$. In the Gulf of Aden, no oxygen measurements were available for the sampling period. According to Beckmann (1984, unpubl.) minimum oxygen values of $<0.4 \mathrm{ml} \mathrm{O}_{2} \mathrm{l}^{-1}$ are found in this area between 150 and $500 \mathrm{~m}$

\section{Total plankton biomass}

Table 2 summarizes the biomass values of total $0.055 \mathrm{~mm}$ mesh net plankton in the 5 regions investigated during the summer survey; the results are grouped into 4 vertical zones as defined by Weikert (1982): epipelagic $(0-100 \mathrm{~m})$, upper mesopelagic (a) $\mathrm{O}_{2}$-gradient $(100-250 \mathrm{~m})$, (b) $\mathrm{O}_{2}$-minimum-zone $(250-450 \mathrm{~m})$ and lower meso-/upper bathypelagic (450-1050 m). In the Strait of Bab al Mandab minimum oxygen concentrations were seen as shallow as $60 \mathrm{~m}$ (Fig. 2): for comparison, however, the vertical integration of biomass values in this region was done in the same manner as at all other sites.

Day-night differences. Biomass differences between day and night within each region were usually minor in the 4 vertical depth zones (Table 2) and statistically not significant (central Red Sea, Region D, 0-100 m, Mann-Whitney $U$-test, $\mathrm{p}>0.1$ ). However, the upper limit of biomass values in the epipelagic zone was generally higher during the night than during the day (Table 2), indicating some upward vertical migration of larger zooplankters from deeper layers.

South-north differences. For regional comparison of plankton biomass, only the epipelagic zone $(0-100 \mathrm{~m})$ will be considered, since the largest data set was avail- able for this zone. Within the central-northern Red Sea, no significant differences in plankton biomass were found between the 3 northernmost (Region E) and the central (Region D) stations (Mann-Whitney $U$-test, $p<0.1$ ). Thus, Regions D and E are treated together in the following comparison. Between the centralnorthern and the southern Red Sea plankton biomass increased significantly by a factor of 2 to 3 (MannWhitney $U$-Test, $\mathrm{p}<0.05$; Table 2 ). In the southern Red Sea and in the Gulf of Aden biomass values were similar (ca $15 \mathrm{~g} \mathrm{~m}^{-2}$ ), whereas exceptionally high biomass values of 30 to $50 \mathrm{~g} \mathrm{~m}^{-2}$ occurred at Bab al Mandab. These were about 5 to 10 times higher than in the north.

Vertical distribution. Maximum biomass values always occurred in the epipelagic zone, at $0-100 \mathrm{~m}$ (Table 2, Fig. 3). Within this depth zone, maximum biomass concentrations were generally found above or near the strong thermocline, from 0 to $40 \mathrm{~m}(80 \mathrm{~m})$ (Fig. 3). A secondary peak in biomass concentration found in the 80 to $100 \mathrm{~m}$ layer at Bab al Mandab during July was caused by a high number of medium-sized medusae and non-copepod crustaceans, which were not present during August.

Below the epipelagic zone, biomass concentrations rapidly decreased with depth by 1 to 2 orders of magnitude to minimal values of 1 to $10 \mathrm{mg} \mathrm{m}^{-3}$ in all depth layers below $450 \mathrm{~m}$ (Fig. 3). The vertical gradient in total plankton biomass between the epipelagic and the adjacent $100-250 \mathrm{~m}$ depth layer was stronger in the subregions of the Red Sea (by a factor of 3 to 4) than in the Gulf of Aden and the Strait of Bab al Mandab (by a factor of 2) (Table 2).

\section{Total metazoan composition and abundance by number}

South-north differences. The numerical abundance of total metazoans and major metazoan taxa in the 4 depth zones is shown in Table 3 for the 6 locations investigated. In the epipelagic zone, total abundance by number was in general higher in the southern Red Sea and at Bab al Mandab as compared to the centralnorthern area (by a factor of 2). This south-to-north decrease was lower, however, than that of total biomass based on a larger number of stations. In the Gulf of Aden, total abundance values were similar to those found in the central-northern Red Sea.

Copepoda were the dominant taxa at all stations investigated, contributing 84 to $92 \%$ to the total number of metazoans in each of the 4 depth zones sampled (Table 3). Nauplii and copepodids I to VI shared similar proportions of 30 to $50 \%$ of the total each. Appendicularians and molluscs ranked second 
Table 2. Biomass of $0.055 \mathrm{~mm}$ mesh net plankton ( $\mathrm{g}$ wet wt beneath $1 \mathrm{~m}^{2}$ ) in the Gulf of Aden and in different regions of the Red Sea during summer 1987. Stations are listed in geographical order from south to north. D: day; N: night; - no data

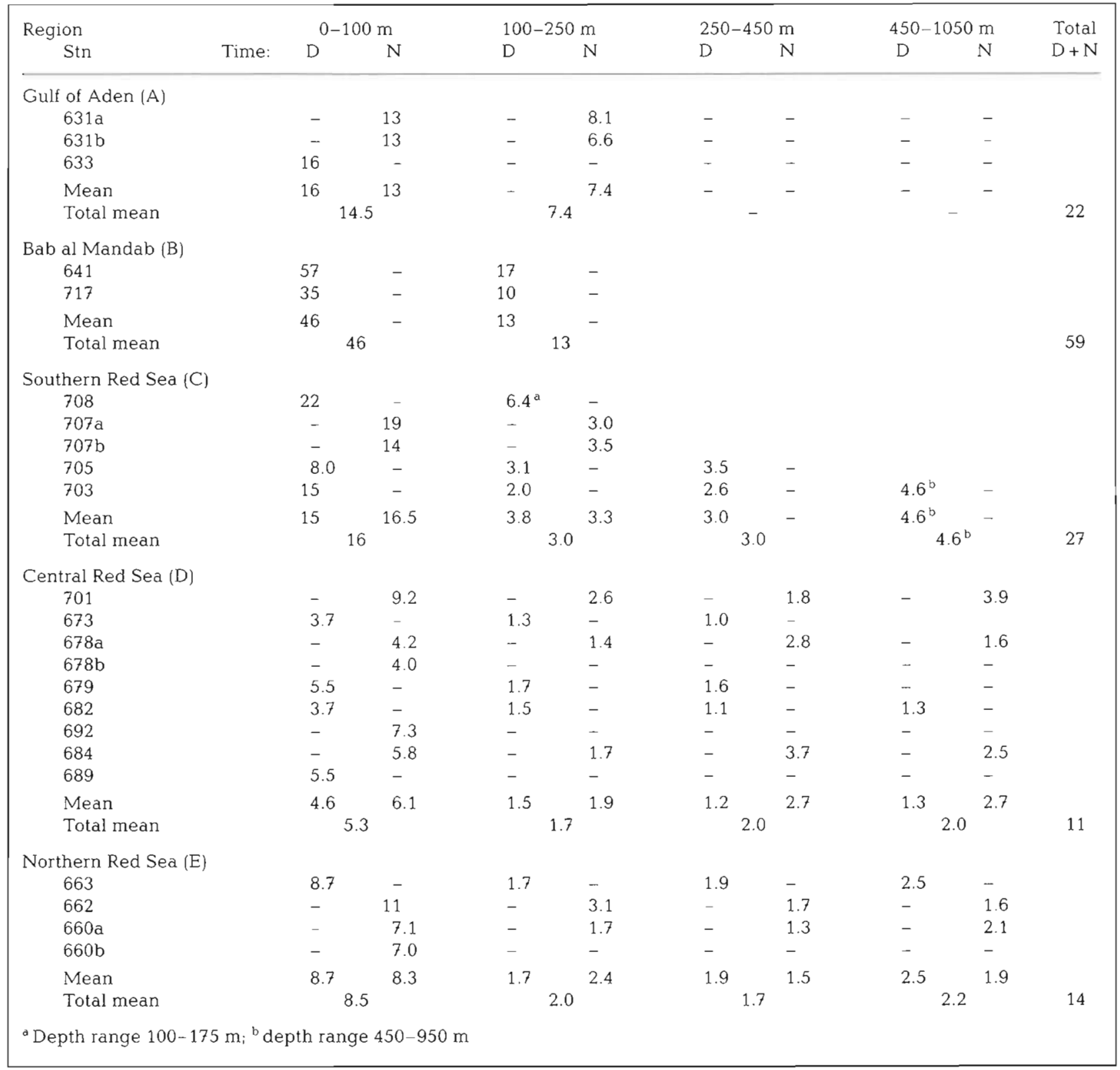

or third, with percentages of mostly 2 to $4 \%$; higher relative abundances were found for these 2 groups in the shallow region of the southern Red Sea (Stn 708), where they contributed $8 \%$ each to the total numbers. Molluscs at this station consisted mainly of bivalve larvae, whereas at all other sites pteropod larvae (mainly Limacina spp. and Creseis spp.) dominated. The group 'other crustaceans' consisted of larval and adult euphausiids, amphipods, decapods, cladocerans, isopods, and individual mysids, as well as larval cirripeds. Unusual ascothoracid larvae as described by Boxshall \& Böttger-Schnack (1988) and several types of Hansen's y-larvae (Crustacea: Maxillopoda: Facetotecta; see Grygier 1987) were found at all stations investigated, the latter showing maximum abundances in the Strait of Bab al Mandab (2 to 5 ind. $\mathrm{m}^{-3}$ at 100 to $200 \mathrm{~m}$ ). Individual nauplii of another type of ascothoracids, which were tentatively identified as Petrarcidae (Grygier 1993), were found in the central and southern Red Sea. The group 'other metazoans' consisted mainly of meroplanktic larval forms (see below) as well as of fish and Branchiostoma larvae, turbellarians and individual insects (Halobates). 

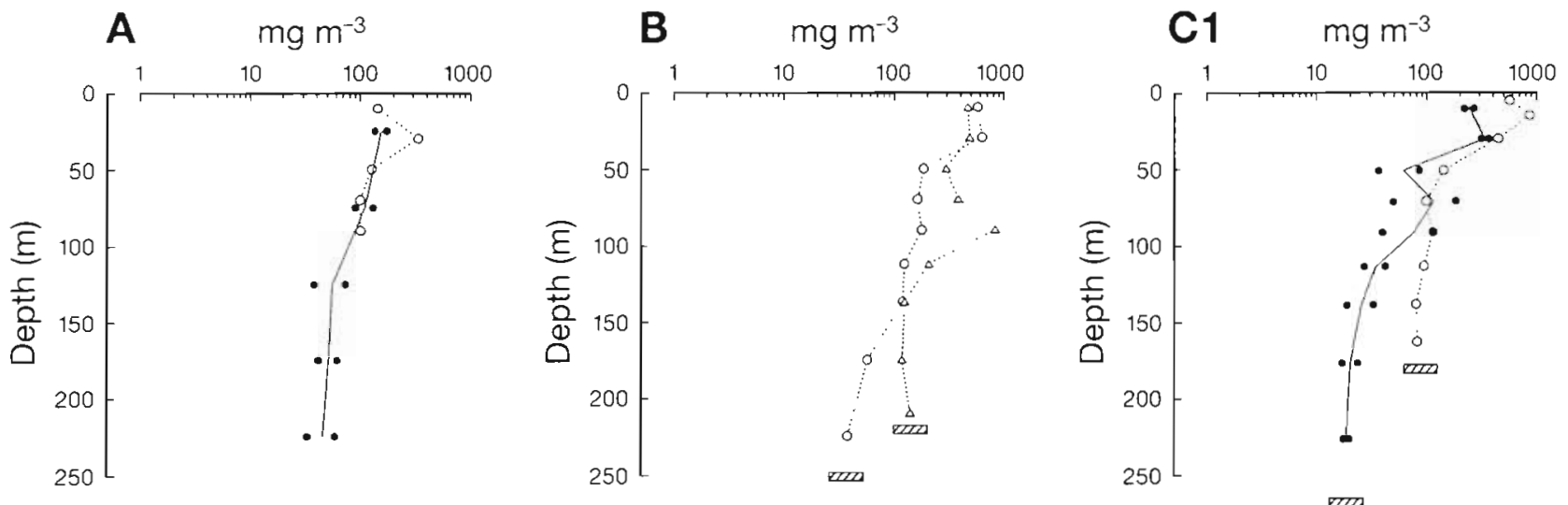

\section{C2 $\mathrm{mg} \mathrm{m}^{-3}$}
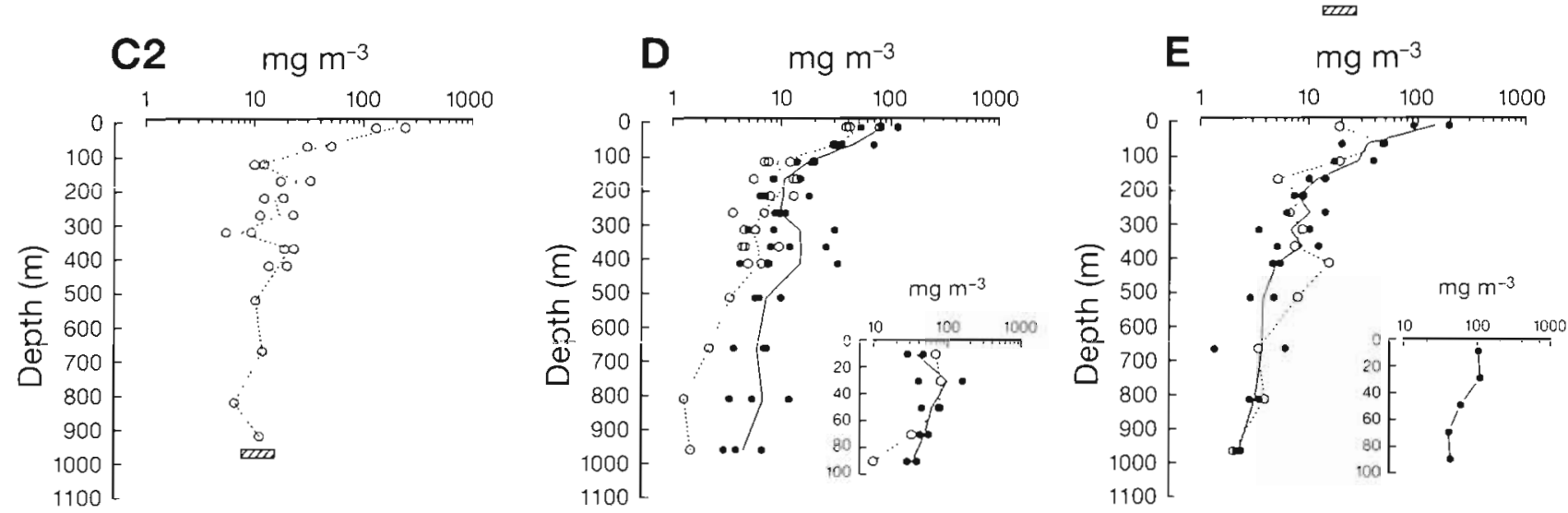

Fig. 3. Vertical distribution of total plankton biomass in the 5 regions. A: Gulf of Aden; B: Bab al Mandab sampled only during the day on July $12(\Delta)$ and August $6(0)$; C: southern Red Sea (C1: shallow; C2: deep); D: central Red Sea; E: northern Red Sea.

(०) Daytime; $(\bullet)$ nighttime. Dashed and solid lines indicate arithmetic means. Note the logarithmic scale. (ש) Bottom

Table 3. Abundance of metazoan taxa (individuals beneath $0.25 \mathrm{~m}^{2}$ ) in different regions of the Red Sea and in the Gulf of Aden during summer 1987. D: day; N: night; -: no data

\begin{tabular}{|c|c|c|c|c|c|c|c|c|}
\hline \multirow{5}{*}{ Taxon } & & \multirow{2}{*}{\multicolumn{2}{|c|}{ Gulf of Aden }} & \multirow{5}{*}{$\begin{array}{c}\text { Babal } \\
\text { Mandab } \\
717 \\
\text { D }\end{array}$} & \multicolumn{4}{|c|}{ Red Sea } \\
\hline & & & & & \multicolumn{2}{|c|}{ South } & \multirow[t]{2}{*}{ Central } & \multirow[t]{2}{*}{ North } \\
\hline & & & & & Shallow & Deep & & \\
\hline & Stn: & 631 & 633 & & 708 & 703 & 682 & 663 \\
\hline & Time: & $\mathrm{N}$ & $\mathrm{D}$ & & $\mathrm{D}$ & $\mathrm{D}$ & $\mathrm{D}$ & $\mathrm{D}$ \\
\hline \multicolumn{9}{|c|}{ Copepodids I-VI } \\
\hline $0-100 \mathrm{~m}$ & & 130000 & 84000 & 140000 & 305000 & 190000 & 80000 & 68000 \\
\hline $100-250 \mathrm{~m}$ & & 35000 & - & 27000 & $91000^{\text {a }}$ & 31000 & 21000 & 23000 \\
\hline $250-450 \mathrm{~m}$ & & - & - & & & 33000 & 13000 & 14000 \\
\hline $450-1050 \mathrm{~m}$ & & - & - & & & $26000^{b}$ & 11000 & 9800 \\
\hline \multicolumn{9}{|c|}{ Copepod nauplii } \\
\hline $0-100 \mathrm{~m}$ & & 85500 & 97000 & 210000 & 180000 & 160000 & 100000 & 87000 \\
\hline $100-250 \mathrm{~m}$ & & 11000 & - & 17000 & $22000^{\circ}$ & 13000 & 22000 & 24500 \\
\hline $250-450 \mathrm{~m}$ & & - & - & & & 12000 & 7600 & 7200 \\
\hline $450-1050 \mathrm{~m}$ & & - & - & & & $29000^{b}$ & 17500 & 12000 \\
\hline \multicolumn{9}{|l|}{ Medusae } \\
\hline $0-100 \mathrm{~m}$ & & 260 & 170 & 28 & 55 & 630 & 620 & 340 \\
\hline $100-250 \mathrm{~m}$ & & 6 & - & 33 & $18^{\circ}$ & 12 & 30 & 58 \\
\hline $250-450 \mathrm{~m}$ & & - & - & & & 1 & 25 & 12 \\
\hline $450-1050 \mathrm{~m}$ & & - & - & & & $0^{b}$ & 5 & 3 \\
\hline
\end{tabular}


Table 3 (continued)

\begin{tabular}{|c|c|c|c|c|c|c|c|c|}
\hline \multirow[t]{5}{*}{ Taxon } & \multirow{5}{*}{$\begin{array}{l}\text { Stn: } \\
\text { Time: }\end{array}$} & \multirow{2}{*}{\multicolumn{2}{|c|}{ Gulf of Aden }} & \multirow{5}{*}{$\begin{array}{c}\text { Bab al } \\
\text { Mandab } \\
717 \\
\text { D }\end{array}$} & \multicolumn{4}{|c|}{ Red Sea } \\
\hline & & & & & So & & \multirow{4}{*}{$\begin{array}{c}\text { Central } \\
682 \\
\text { D }\end{array}$} & \multirow{4}{*}{$\begin{array}{c}\text { North } \\
663 \\
\text { D }\end{array}$} \\
\hline & & \multirow{3}{*}{$\begin{array}{c}631 \\
\mathrm{~N}\end{array}$} & \multirow{3}{*}{$\begin{array}{c}633 \\
D\end{array}$} & & \multirow{3}{*}{$\begin{array}{c}\text { Shallow } \\
708 \\
\text { D }\end{array}$} & \multirow{3}{*}{$\begin{array}{c}\text { Deep } \\
703 \\
D\end{array}$} & & \\
\hline & & & & & & & & \\
\hline & & & & & & & & \\
\hline \multicolumn{9}{|c|}{ Siphonophores } \\
\hline $0-100 \mathrm{~m}$ & & 14 & 67 & 110 & 41 & 100 & 280 & 230 \\
\hline $100-250 \mathrm{~m}$ & & 8 & - & 32 & $6^{\mathrm{a}}$ & 4 & 5 & 20 \\
\hline $250-450 \mathrm{~m}$ & & - & - & & & 3 & 5 & 11 \\
\hline $450-1050 \mathrm{~m}$ & & - & - & & & $20^{b}$ & 6 & 33 \\
\hline \multicolumn{9}{|l|}{ Ostracods } \\
\hline $0-100 \mathrm{~m}$ & & 1000 & 1250 & 2500 & 800 & 640 & 170 & 26 \\
\hline $100-250 \mathrm{~m}$ & & 1000 & - & 2100 & $900^{\mathrm{a}}$ & 1100 & 730 & 510 \\
\hline $250-450 \mathrm{~m}$ & & - & - & & & 1100 & 630 & 290 \\
\hline $450-1050 \mathrm{~m}$ & & - & - & & & $1100^{b}$ & 920 & 760 \\
\hline \multicolumn{9}{|c|}{ Other crustaceans } \\
\hline $0-100 \mathrm{~m}$ & & 450 & 390 & 1450 & 710 & 400 & 240 & 140 \\
\hline $100-250 \mathrm{~m}$ & & 140 & - & 510 & $530^{d}$ & 190 & 30 & 55 \\
\hline $250-450 \mathrm{~m}$ & & - & - & & & 115 & 13 & 38 \\
\hline $450-1050 \mathrm{~m}$ & & - & - & & & $63^{b}$ & 19 & 19 \\
\hline \multicolumn{9}{|l|}{ Molluscs } \\
\hline $0-100 \mathrm{~m}$ & & 12000 & 8100 & 17000 & 33000 & 11000 & 11000 & 9900 \\
\hline $100-250 \mathrm{~m}$ & & 430 & - & 2700 & $25000^{a}$ & 530 & 440 & 390 \\
\hline $250-450 \mathrm{~m}$ & & - & - & & & 550 & 200 & 250 \\
\hline $450-1050 \mathrm{~m}$ & & - & - & & & $700^{b}$ & 270 & 345 \\
\hline \multicolumn{9}{|c|}{ Appendicularians } \\
\hline $0-100 \mathrm{~m}$ & & 9300 & 16000 & 19000 & 45000 & 20000 & 4600 & 8050 \\
\hline $100-250 \mathrm{~m}$ & & 380 & - & 730 & $1400^{a}$ & 160 & 350 & 2100 \\
\hline $250-450 m$ & & - & - & & & 110 & 36 & 64 \\
\hline $450-1050 \mathrm{~m}$ & & - & - & & & $97^{b}$ & 32 & 9 \\
\hline \multicolumn{9}{|l|}{ Thaliaceans } \\
\hline $0-100 \mathrm{~m}$ & & 780 & 170 & 1150 & 150 & 1700 & 9 & 145 \\
\hline $100-250 \mathrm{~m}$ & & 0 & - & 22 & $0^{a}$ & 0 & 0 & 31 \\
\hline $250-450 m$ & & - & - & & & 0 & 0 & 0 \\
\hline $450-1050 \mathrm{~m}$ & & - & - & & & $1^{b}$ & 0 & 0 \\
\hline Chaetognath & & & & & & & & \\
\hline $0-100 \mathrm{~m}$ & & 2700 & 2700 & 2400 & 3300 & 6100 & 1500 & 2000 \\
\hline $100-250 m$ & & 84 & - & 350 & $1050^{a}$ & 230 & 250 & 260 \\
\hline $250-450 \mathrm{~m}$ & & - & - & & & 175 & 58 & 110 \\
\hline $450-1050 \mathrm{~m}$ & & - & - & & & $125^{b}$ & 34 & 130 \\
\hline Polychaetes & & & & & & & & \\
\hline $0-100 \mathrm{~m}$ & & 610 & 1100 & 3000 & 1750 & 1750 & 110 & 340 \\
\hline $100-250 \mathrm{~m}$ & & 940 & - & 1600 & $2400^{a}$ & 360 & 620 & 490 \\
\hline $250-450 m$ & & - & - & & & 140 & 380 & 380 \\
\hline $450-1050 \mathrm{~m}$ & & - & - & & & $180^{b}$ & 105 & 120 \\
\hline Other metazc & & & & & & & & \\
\hline $0-100 \mathrm{~m}$ & & 690 & 830 & 1400 & 890 & 570 & 110 & 88 \\
\hline $100-250 \mathrm{~m}$ & & 520 & - & 1200 & $240^{\circ}$ & 240 & 24 & 56 \\
\hline $250-450 \mathrm{~m}$ & & - & - & & & 310 & 69 & 16 \\
\hline $450-1050 \mathrm{~m}$ & & - & - & & & $110^{\mathrm{b}}$ & 46 & 31 \\
\hline Total metazo & & & & & & & & \\
\hline $0-100 \mathrm{~m}$ & & 250000 & 210000 & 405000 & 570000 & 400000 & 200000 & 175000 \\
\hline $100-250 \mathrm{~m}$ & & 50000 & - & 53000 & $140000^{\circ}$ & 46000 & 46000 & 51000 \\
\hline $250-450 \mathrm{~m}$ & & - & - & & & 47000 & 22000 & 23000 \\
\hline $450-1050 \mathrm{~m}$ & & - & - & & & $57000^{b}$ & 30000 & 23000 \\
\hline
\end{tabular}


Most of the separated metazoan taxa followed the south-to-north decrease in number observed for total metazoans (Table 3). For only a few taxa, such as chaetognaths, salps and medusae, was no consistent south-to-north gradient evident (Table 3 ). The greatest decrease in abundance was noted for ostracods, polychaetes, and for the group 'other metazoans': varying by a factor of 5 to 10 from south to north. The occurrence of larval bryozoans, brachiopods and anthozoans, which were included in this group, was restricted to the southern area only. Anthozoan larvae dominated total plankton biomass at the southern shallow station (Stn 708), and large numbers of gelatinous zooplankton occurred at Bab al Mandab during August; both taxa increased the observed total plankton biomass, but contributed little to total number of metazoans.

Vertical distribution. Maximum concentrations of total metazoans were always found in the upper 20 or $50 \mathrm{~m}$ depth layer. Values ranged between $10^{4}$ and $10^{5}$ ind. $\mathrm{m}^{-3}$ according to the region sampled; they decreased by about 2 orders of magnitude to mini- mum values of 100 to $200 \mathrm{ind} . \mathrm{m}^{-3}$ in the 900 to $1050 \mathrm{~m}$ layer (Fig. 4). In the deep oceanic regions of the Red Sea, a small secondary maximum was situated between $150(200 \mathrm{~m})$ and $400 \mathrm{~m}$ depth, in the upper part of the oxygen minimum zone (see Fig. 2). In the shallow region of the southern Red Sea (C1) the vertical distribution of total metazoan abundance differed from all other sites: below the very high surface concentrations of nearly 100000 ind. $\mathrm{m}^{-3}$ in the upper $20 \mathrm{~m}$, above the shallow thermocline, nearly homogeneous concentrations of about 5000 to 10000 ind $\mathrm{m}^{-3}$ were found down to the bottom at $175 \mathrm{~m}$ (Fig. 4).

\section{Total copepodids}

Among copepodids I to VI, the 3 suborders Calanoida, Cyclopoida and Poecilostomatoida dominated, together accounting for 80 to $95 \%$ of the total numbers (Table 4). Harpacticoida mostly ranked fourth, Siphonostomatoida were present in very low percent-
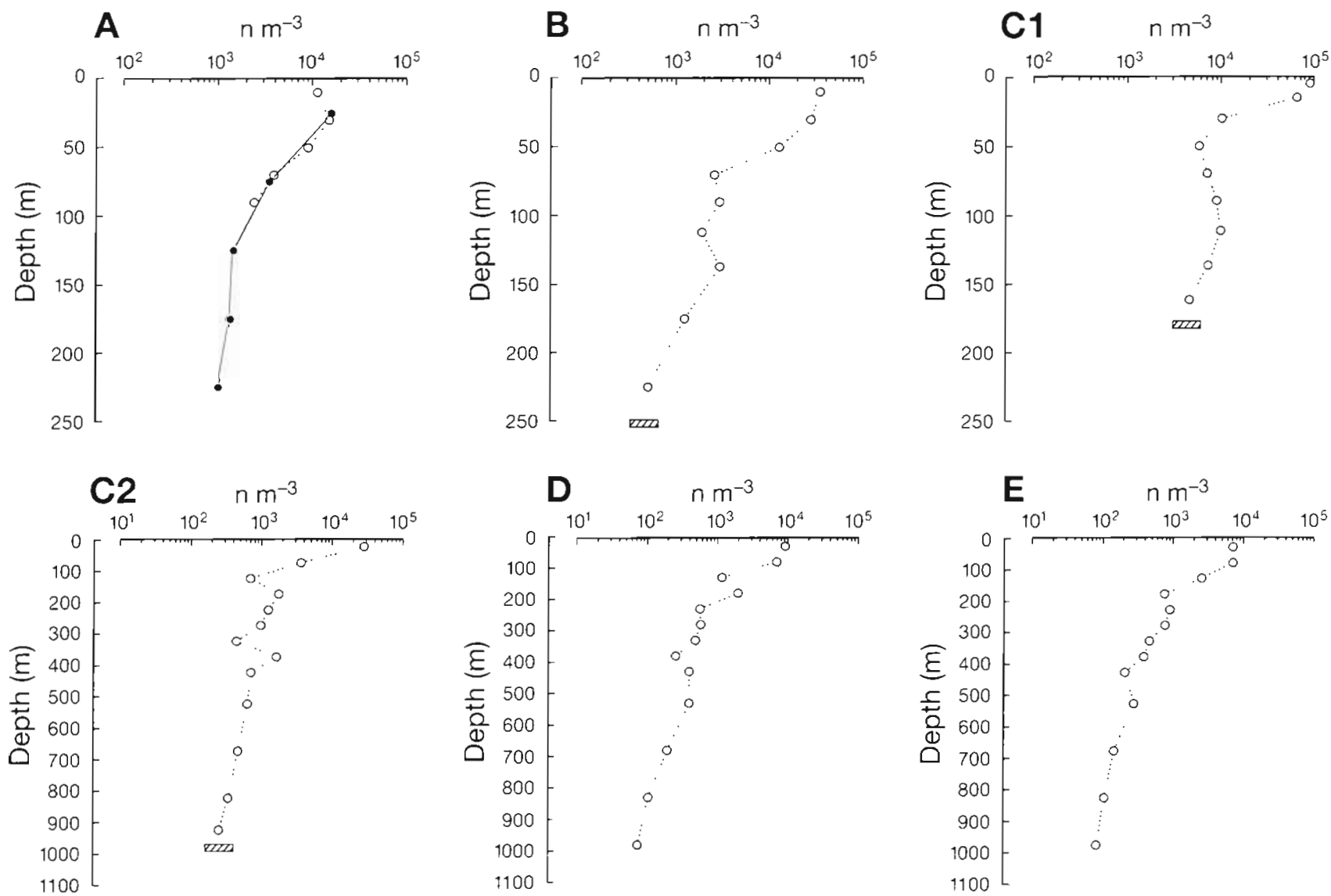

Fig. 4. Vertical distribution of total metazoan abundance in the 5 regions during daytime, except for Gulf of Aden (A) data which include nighttime series. B: Bab al Mandab; C: southern Red Sea (C1: shallow; C2: deep); D: central Red Sea; E: northern Red Sea. (m) Bottom 
Table 4. Abundance (individuals beneath $0.25 \mathrm{~m}^{2}$ ) of copepod suborders in the Gulf of Aden and different regions of the Red Sea during summer 1987. Daytime values unless otherwise indicated. 0: no individuals; -: no data

\begin{tabular}{|c|c|c|c|c|c|c|c|c|}
\hline \multirow{3}{*}{$\begin{array}{l}\text { Copepod } \\
\text { suborder }\end{array}$} & \multirow{2}{*}{\multicolumn{3}{|c|}{ Gulf of Aden }} & \multirow{3}{*}{$\begin{array}{c}\text { Babal } \\
\text { Mandab } \\
717\end{array}$} & \multicolumn{4}{|c|}{ Red Sea } \\
\hline & & & & & \multicolumn{2}{|c|}{ South } & \multirow{2}{*}{$\begin{array}{c}\text { Central } \\
682\end{array}$} & \multirow{2}{*}{$\begin{array}{c}\text { North } \\
663\end{array}$} \\
\hline & Stn: & 631 (Night) & 633 & & $\begin{array}{c}\text { Shallow } \\
708\end{array}$ & $\begin{array}{l}\text { Deep } \\
703\end{array}$ & & \\
\hline \multicolumn{9}{|l|}{ Calanoida } \\
\hline $0-100 \mathrm{~m}$ & & 50000 & 25000 & 43500 & 36000 & 36000 & 28000 & 22000 \\
\hline $100-250 \mathrm{~m}$ & & 8800 & - & 4400 & $7400^{d}$ & 3800 & 3300 & 3400 \\
\hline $250-450 \mathrm{~m}$ & & - & - & & & 1750 & 975 & 920 \\
\hline $450-1050 \mathrm{~m}$ & & - & - & & & $1800^{b}$ & 770 & 1100 \\
\hline \multicolumn{9}{|l|}{ Cyclopoida } \\
\hline $0-100 \mathrm{~m}$ & & 46500 & 24000 & 35000 & 220000 & 54000 & 20000 & 20000 \\
\hline $100-250 \mathrm{~m}$ & & 3200 & - & 5700 & $29000^{a}$ & 3200 & 5100 & 5300 \\
\hline $250-450 \mathrm{~m}$ & & - & - & & & 380 & 500 & 500 \\
\hline $450-1050 \mathrm{~m}$ & & - & - & & & $415^{b}$ & 250 & 310 \\
\hline \multicolumn{9}{|c|}{ Poecilostomatoida } \\
\hline $0-100 \mathrm{~m}$ & & 30000 & 29000 & 55000 & 25500 & 54500 & 21000 & 16000 \\
\hline $100-250 \mathrm{~m}$ & & 19000 & - & 16000 & $30500^{\circ}$ & 21000 & 12000 & 12000 \\
\hline $250-450 m$ & & - & - & & & 29000 & 11000 & 12000 \\
\hline $450-1050 \mathrm{~m}$ & & - & - & & & $22000^{b}$ & 9000 & 7900 \\
\hline \multicolumn{9}{|c|}{ Siphonostomatoida } \\
\hline $0-100 \mathrm{~m}$ & & 6 & 5 & 11 & 9 & 75 & 78 & 73 \\
\hline $100-250 \mathrm{~m}$ & & 2 & - & 0 & $42^{\circ}$ & 0 & 25 & 40 \\
\hline $250-450 \mathrm{~m}$ & & - & - & & & 0 & 14 & 10 \\
\hline $450-1050 \mathrm{~m}$ & & - & - & & & $0^{b}$ & 41 & 15 \\
\hline \multicolumn{9}{|c|}{ Harpacticoida } \\
\hline $0-100 \mathrm{~m}$ & & 6500 & 5300 & 8100 & 19000 & 50000 & 9700 & 9200 \\
\hline $100-250 \mathrm{~m}$ & & 1800 & - & 2200 & $24000^{a}$ & 3100 & 1250 & 1900 \\
\hline $250-450 \mathrm{~m}$ & & - & - & & & 1200 & 650 & 550 \\
\hline $450-1050 \mathrm{~m}$ & & - & - & & & $1550^{b}$ & 780 & 420 \\
\hline \multicolumn{9}{|c|}{ Mormonilloida } \\
\hline $0-100 \mathrm{~m}$ & & 2 & 33 & 370 & 65 & 0 & 0 & 0 \\
\hline $100-250 \mathrm{~m}$ & & 1600 & - & 960 & $16^{\mathrm{a}}$ & 1 & 0 & 0 \\
\hline $250-450 \mathrm{~m}$ & & - & - & & & 17 & 0 & 0 \\
\hline $450-1050 \mathrm{~m}$ & & - & - & & & $4^{b}$ & 0 & 0 \\
\hline
\end{tabular}

ages only $(<1 \%)$. The occurrence of Mormonilloida was restricted to the Gulf of Aden and southern Red Sea; they were absent in the central-northern part (Table 4)

In the epipelagic zone, calanoids, cyclopoids and poecilostomatoids were usually present in similar percentages, each group including 20 to $35 \%$ of all copepodids. In the shallow region of the southern Red Sea, however, cyclopoids (Oithona and Paroithona) contributed over $70 \%$ to the total numbers, whereas calanoids amounted to less than $20 \%$ at this station (Stn 708) and at the adjacent deep water station (Stn 703) in the southern Red Sea. Below the epipelagic zone, the proportion of poecilostomatoids (mainly Oncaea) strongly increased: in the $100-250 \mathrm{~m}$ layer they mostly contributed more than $50 \%$ to all copepodids, and in the 2 meso- and bathypelagic zones between 250 and $1050 \mathrm{~m}$ depth they were strongly dominant, with more than $80 \%$ of all copepodids (Table 4). Regional differences were usually minor in these depths below the epipelagic zone; only at the more shallow station in the southern Red Sea did harpacticoids (mainly Microsetella) account for a large proportion (26\%) of all copepodids in the 100 to $250 \mathrm{~m}$ depth layer.

\section{Non-calanoid copepodids}

South-north differences in general. Table 5 presents an overview of the abundance of non-calanoid copepod species or genera at the 6 stations investigated and their relative percentages within the respective suborder. The number of species would have been higher if 
Table 5. Abundance (individuals beneath $0.25 \mathrm{~m}^{2}$ ) of non-ralanoid copepod species or genera in the Gulf of Aden and different regions of the Red Sea during summer 1987. shall.: shallow; D: day; N: night. Sex/Stage: F, females; M, males; 1 , late juveniles; 2 , early juveniles; 3 , various juveniles. 0 : no individuals ${ }_{i}+$ : present, but species not evaluated quantitatively; ${ }^{\cdot}$ species not present in the central-northern Red Sea

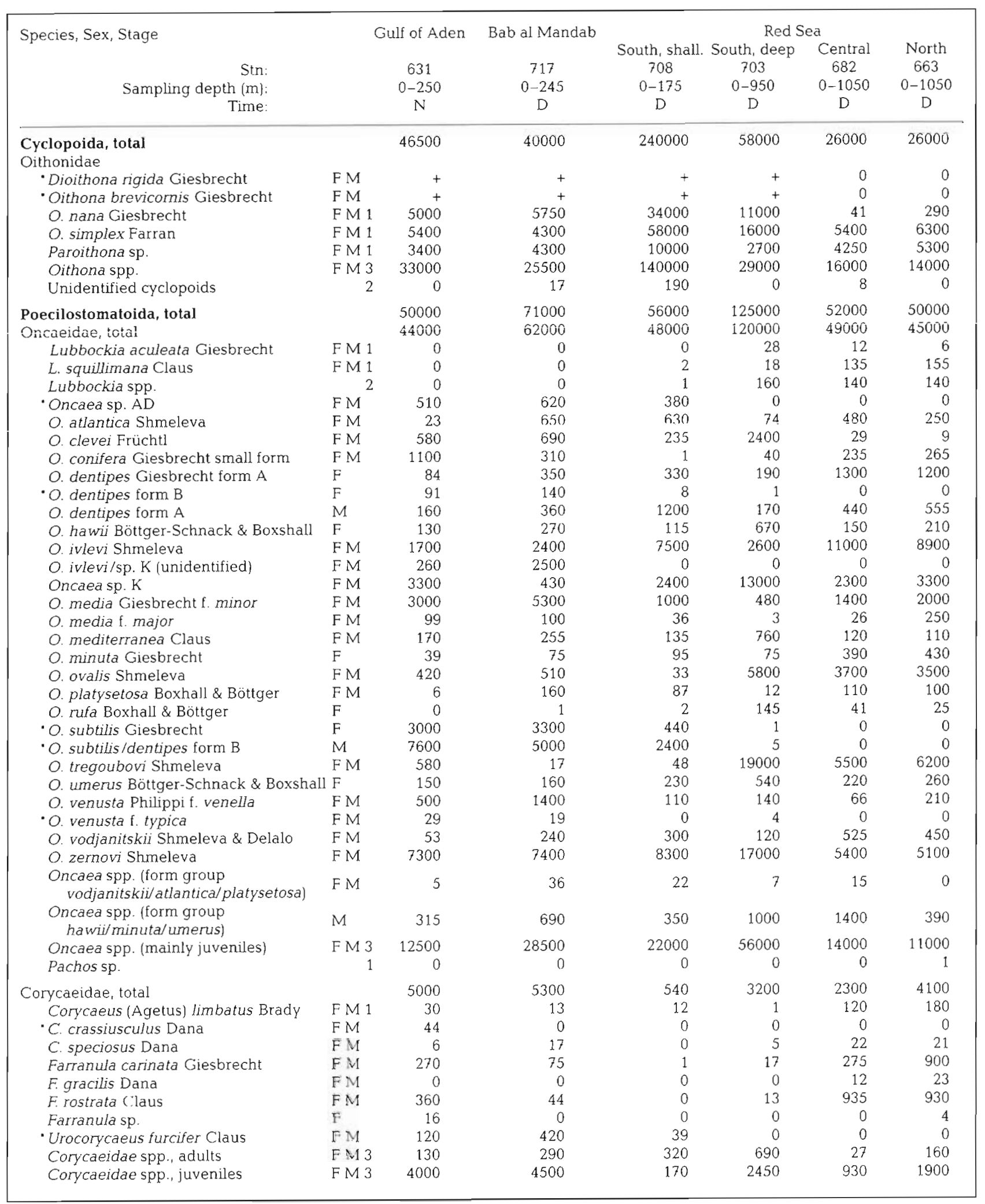


Table 5 (continued)

\begin{tabular}{|c|c|c|c|c|c|c|c|}
\hline \multirow{5}{*}{$\begin{array}{l}\text { Species, Sex, Stage } \\
\qquad \begin{array}{r}\text { Stn: } \\
\text { Sampling depth }(\mathrm{m}): \\
\text { Time: }\end{array}\end{array}$} & \multirow{2}{*}{\multicolumn{2}{|c|}{ Gulf of Aden }} & \multirow{5}{*}{$\begin{array}{l}\text { Bab al Mandab } \\
\qquad \begin{array}{c}717 \\
0-245 \\
\text { D }\end{array}\end{array}$} & \multicolumn{4}{|c|}{ Red Sea } \\
\hline & & & & South, shall. & South, deep & Central & North \\
\hline & & 631 & & 708 & 703 & 682 & 663 \\
\hline & & $0-250$ & & $0-175$ & $0-950$ & $0-1050$ & $0-1050$ \\
\hline & & $N$ & & $\mathrm{D}$ & D & $\mathrm{D}$ & $\mathrm{D}$ \\
\hline \multicolumn{2}{|l|}{ Sapphirinidae, total } & 370 & 110 & 70 & 135 & 130 & 120 \\
\hline - Copilia lata Giesbrecht & $F M$ & 0 & 6 & 0 & 0 & 0 & 0 \\
\hline C. mirabilis Dana & $F M 1$ & 20 & 23 & 2 & 63 & 23 & 66 \\
\hline C. quadrata Dana & $\mathrm{F}$ & 0 & 0 & 0 & 4 & 0 & 0 \\
\hline Copilia spp. & 2 & 4 & 0 & 0 & 18 & 1 & 1 \\
\hline - Sapphinina intestinata Giesbrecht & $F M$ & 0 & 2 & 0 & 1 & 0 & 0 \\
\hline S. metallina Dana & FM 1 & 8 & 5 & 0 & 4 & 26 & 43 \\
\hline S. nigromaculata Claus & FM & 0 & 8 & 0 & 2 & 0 & 1 \\
\hline S. opalina Dana & $\mathrm{FM}$ & 0 & 4 & 0 & 1 & 0 & 1 \\
\hline S. ovatolanceolata-gemma Dana & $\mathrm{FM}$ & 0 & 2 & 0 & 0 & 0 & 0 \\
\hline Sapphirina spp. (mainly juveniles) & FM 3 & 7 & 18 & 2 & 4 & 53 & 6 \\
\hline - Vettoria granulosa Giesbrecht & $\mathrm{FM}$ & 0 & 18 & 66 & 0 & 0 & 0 \\
\hline$V$ parva Farran & $\mathrm{FM}$ & 2 & 14 & 0 & 4 & 8 & 5 \\
\hline Vettoria spp. & 3 & 330 & 7 & 0 & 34 & 17 & 1 \\
\hline Saphirella-like copepodids & 2 & 380 & 3300 & 6000 & 1700 & 83 & 790 \\
\hline Unidentified poecilostomatoids & 3 & 770 & 990 & 150 & 2900 & 780 & 130 \\
\hline \multicolumn{2}{|l|}{ Harpacticoida, total } & 8300 & 10000 & 43000 & 56000 & 12000 & 12000 \\
\hline Clytemnestra rostrata Brady & FM 1 & 4 & 6 & 1 & 0 & 0 & 3 \\
\hline C. scutellata Dana & FM 1 & 150 & 30 & 120 & 8 & 8 & 3 \\
\hline - Euterpina acutifrons Dana & $\mathrm{FM} 3$ & 6 & 1500 & 140 & 260 & 0 & 0 \\
\hline Macrosetella gracilis Dana & FM 1 & 380 & 60 & 1100 & 3000 & 110 & 470 \\
\hline $\begin{array}{l}\text { Microsetella norvegica Boeck } \\
M \text {. rosea Dana }\end{array}$ & $\left.\begin{array}{l}F M 3 \\
F M 3\end{array}\right\}$ & 7800 & 8700 & 42000 & 53000 & 12000 & 11500 \\
\hline - Miracia minor Scott ${ }^{\mathrm{a}}$ & FM & 3 & 6 & 1 & 0 & 0 & 0 \\
\hline \multicolumn{2}{|l|}{$\begin{array}{l}\text { Unidentified harpacticoids } \\
\text { (mainly Longipedia spp.) }\end{array}$} & 8 & 2 & 2 & 64 & 1 & 10 \\
\hline \multirow{3}{*}{$\begin{array}{l}\text { Siphonostomatoida, total } \\
\text { Pontoeciella abyssicola T. Scott } \\
\text { Ratania flava Giesbrecht }\end{array}$} & & 8 & 11 & 51 & 75 & 160 & 140 \\
\hline & FM 3 & 6 & 10 & 51 & 75 & 160 & 130 \\
\hline & FM 1 & 2 & 1 & 0 & 0 & 1 & 7 \\
\hline \multicolumn{8}{|l|}{ Mormonilloida } \\
\hline - Mormonilla minor Giesbrecht & FM 3 & 1600 & 1300 & 81 & 22 & 0 & 0 \\
\hline
\end{tabular}

all species of Oithona and the smaller Corycaeidae could have been identified. Of the 75 species or groups listed in Table 5 about one-half (ca 40) decreased in number from south to north; 16 of these taxa were completely absent in the central-northern area. Moreover, for several Oithona and Oncaea species different morphs or size variants occurred in the Gulf of Aden and the southern Red Sea that were not found in the central-northern area (Table 6). For Oithona species, the identity of these morphs was verified (F. Ferrari pers. comm.), but for Oncaea species they are not yet recorded in the taxonomic literature.

The strongest regional trends in abundance were observed for Oncaea subtilis, Mormonilla minor and Euterpina acutifrons. The numbers of these species decreased from south to north by more than 3 orders of magnitude (Table 5). Differences of at least one order of magnitude were noted for another 7 species. Opposite to the general trend, an increase in abundance from south to north was observed for 19 non-calanoid species or groups (Table 5). Among these, 2 general groups were apparent:

(1) Species which showed a more or less constant increase in numbers from south to north within the Red Sea, and which were rare or absent further south in the Gulf of Aden. These include Lubbockia squillimana, Oncaea rufa, Farranula gracilis, Sapphirina metallina and Pontoeciella abyssicola.

(2) Species which occurred in minimal numbers in the southern Red Sea, but exhibited higher values to the south (in the Gulf of Aden - Bab al Mandab area) as well as to the north (in the central-northern Red Sea). These include Oncaea conifera, O. media f. major, Farranula carinata and $F$. rostrata.

Copepod carcasses and empty exoskeletons were comparably low in abundance among the noncalanoid species during summer. In most cases, less than $10 \%$ of the total standing stock of a given species 
Table 6. Occurrence of different forms or size variants among non-calanoid copepod species in the Red Sea during summer 1987. + : present; $(+)$ solitary finds; - : not present

\begin{tabular}{|c|c|c|}
\hline Species/forms & $\begin{array}{l}\text { Central-northern } \\
\text { Red Sea }\end{array}$ & $\begin{array}{l}\text { Southern } \\
\text { Red Sea }\end{array}$ \\
\hline \multicolumn{3}{|l|}{ Oithonidae } \\
\hline \multirow{3}{*}{$\begin{array}{l}\text { Oithona nana typical form } \\
\text { plumosa form } \\
\text { form } \mathrm{A}\end{array}$} & + & + \\
\hline & - & + \\
\hline & & + \\
\hline \multirow{2}{*}{$\begin{array}{l}\text { O. simplex typical form (short) } \\
\text { long form }\end{array}$} & + & + \\
\hline & - & + \\
\hline \multicolumn{3}{|l|}{ Oncaeidae } \\
\hline \multirow{2}{*}{$\begin{array}{l}\text { Oncaea dentipes form } \mathrm{A} \\
\text { form } \mathrm{B}\end{array}$} & + & + \\
\hline & - & + \\
\hline \multirow{2}{*}{$\begin{array}{l}\text { O. ivlevi typical form } \\
\text { small form }\end{array}$} & + & + \\
\hline & $(+)$ & + \\
\hline \multirow{2}{*}{$\begin{array}{l}\text { O. hawii typical form } \\
\text { long form }\end{array}$} & + & + \\
\hline & - & + \\
\hline \multirow{2}{*}{$\begin{array}{l}\text { O. venusta forma typica } \\
\text { forma venella }\end{array}$} & - & + \\
\hline & + & + \\
\hline
\end{tabular}

in the upper $1050 \mathrm{~m}$ were dead. The only exception was Oncaea sp. K, which had a fairly high proportion of dead individuals throughout the entire region studied $(10$ to $29 \%)$. Some of the southern species, such as Oncaea venusta f. typica, were found in the central Red Sea as empty exaskeletons only. Species which were mainly concentrated in the north such as $O$. tregoubovi, were found with high porportions of carcasses in the southern Red Sea.
Epipelagic zone (0-100 $\mathbf{m})$. Regional differences in the non-calanoid fauna were most pronounced in the epipelagic zone. Based on the similarity in species composition among stations within this depth zone (Tables $7 \& 8$ ) 3 different regions could be distinguished:

(1) The Gulf of Aden and the Bab al Mandab area, where the 3 small oithonid species investigated were more or less equally abundant, each accounting for 7 to $13 \%$ of the total cyclopoids (Table 7 ). Among the poecilostomatoids, Oncaea subtilis strongly dominated. When assuming that most of the males of 'subtilis/dentipes $\mathrm{sp} . \mathrm{B}$ ' belong to $O$. subtilis, this species amounted to 14 to $27 \%$ within the group (Table 7). $O$. zernovi and $O$. media f. minor ranked second and/or third, each accounting for 7 to $15 \%$ of all poecilostomatoids. Among harpacticoids, Euterpina acutifrons was especially abundant in the Strait of Bab al Mandab; accounting for $19 \%$ of this group in that area.

(2) The southern Red Sea, where 2 Oithona species dominated, $O$. simplex and $O$. nana, each contributing about 15 to $25 \%$ within the cyclopoids (Table 7 ). Among poecilostomatoids, Oncaea zernovi and $O$. ivlevi were dominant, with a relative abundance of 10 to $20 \%$ of the total. In this area, the proportion of Oncaea spp. juveniles was conspicuously high (Table 8).

(3) The central-northern Red Sea, where the relative abundance of Oithona nana was strongly reduced and $O$. simplex and Paroithona spp. were the dominant cyclopoid species, each sharing about $20 \%$ within this

Table 7. Abundance (individuals beneath $0.25 \mathrm{~m}^{2}$ ) of selected small oithonid species in the Gulf of Aden and different regions of the Red Sea during summer 1987. D: day; N: night. shall.: shallow; F, females; M, males; 1: late juveniles. 0: no individuals; -: no data

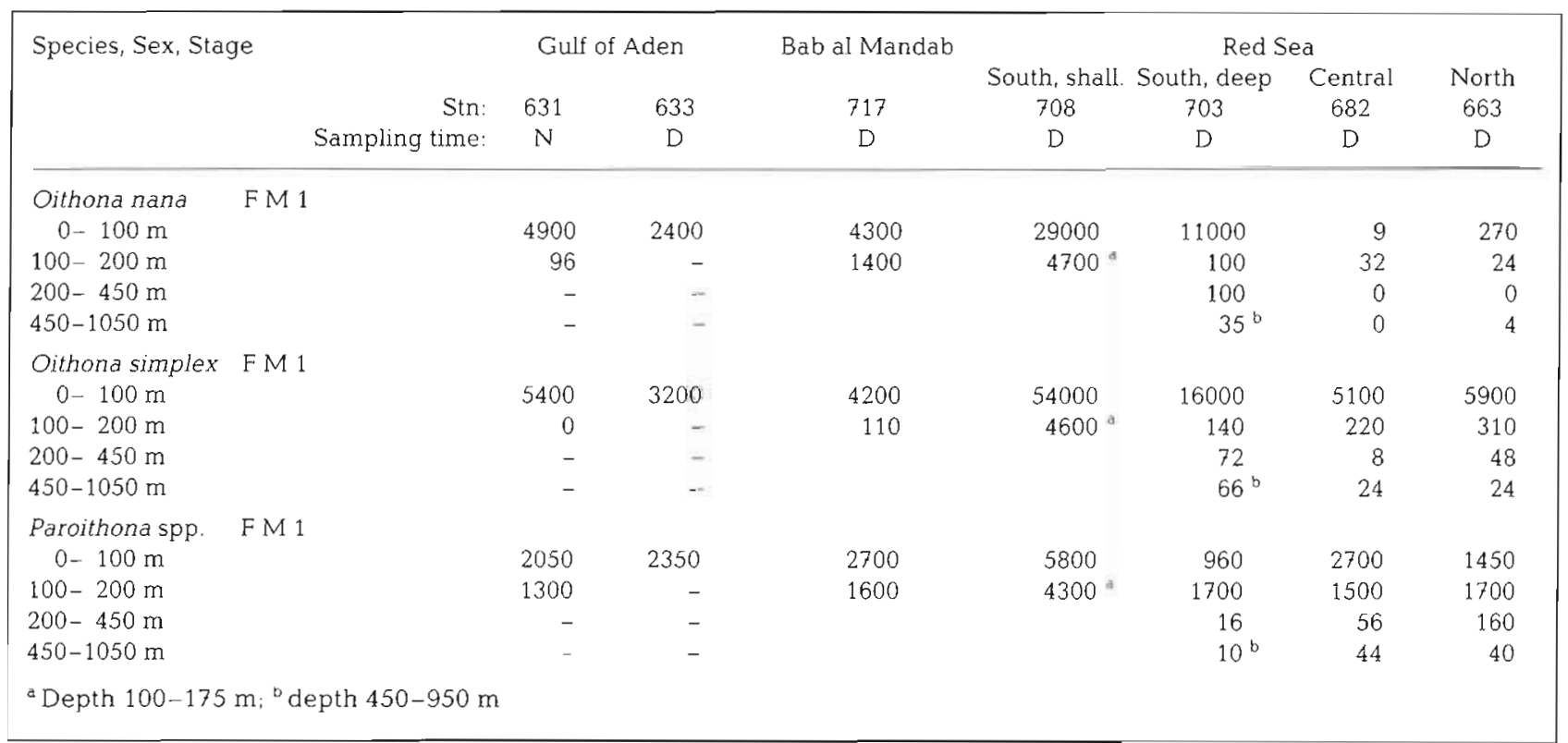


Table 8. Abundance (individuals beneath $0.25 \mathrm{~m}^{2}$ ) of dominant Oncaea species and Oncaea spp. juveniles in the Gulf of Aden and different regions of the Red Sea during summer 1987. Species are listed in alphabetical order. shall.: shallow. F, females; $M$, males; 3 : juveniles. D: day; N: night. 0 : no individuals; -: no data

\begin{tabular}{|c|c|c|c|c|c|c|c|c|}
\hline \multirow[t]{2}{*}{ Species, Sex, Stage } & \multirow[b]{2}{*}{$\begin{array}{r}\text { Stn: } \\
\text { Sampling tıme: }\end{array}$} & \multicolumn{2}{|c|}{ Guif of Aden } & \multirow{2}{*}{$\begin{array}{c}\text { Bab al Mandab } \\
717 \\
D\end{array}$} & \multicolumn{4}{|c|}{ Red Sea } \\
\hline & & $\begin{array}{c}631 \\
N\end{array}$ & $\begin{array}{c}633 \\
D\end{array}$ & & $\begin{array}{c}\text { South, shall. } \\
708 \\
\text { D }\end{array}$ & $\begin{array}{c}\text { South, deep } \\
703 \\
\text { D }\end{array}$ & $\begin{array}{c}\text { Central } \\
682 \\
D\end{array}$ & $\begin{array}{c}\text { North } \\
663 \\
\text { D }\end{array}$ \\
\hline Oncaea sp. AD & FM & & & & & & & \\
\hline $0-100 \mathrm{~m}$ & & 510 & 610 & 620 & 100 & 0 & 0 & 0 \\
\hline $100-250 \mathrm{~m}$ & & 0 & - & 1 & $270^{d}$ & 0 & 0 & 0 \\
\hline $250-450 \mathrm{~m}$ & & - & - & & & 0 & 0 & 0 \\
\hline $450-1050 \mathrm{~m}$ & & - & - & & & 0 & 0 & 0 \\
\hline O. dentipes form $\mathrm{A}$ & $\mathrm{F}$ & & & & & & & \\
\hline $0-100 \mathrm{~m}$ & & 16 & 81 & 240 & 70 & 83 & 470 & 190 \\
\hline $100-250 \mathrm{~m}$ & & 68 & - & 100 & $260^{\mathrm{a}}$ & 105 & 770 & 1000 \\
\hline $250-450 \mathrm{~m}$ & & - & - & & & 0 & 32 & 20 \\
\hline $450-1050 \mathrm{~m}$ & & - & - & & & $2^{b}$ & 24 & 6 \\
\hline O. dentipes form $\mathrm{B}$ & $F$ & & & & & & & \\
\hline $0-100 \mathrm{~m}$ & & 25 & 170 & 140 & 5 & 1 & 0 & 0 \\
\hline $100-250 \mathrm{~m}$ & & 66 & - & 0 & $3^{a}$ & 0 & 0 & 0 \\
\hline $250-450 \mathrm{~m}$ & & - & - & & & 0 & 0 & 0 \\
\hline $450-1050 \mathrm{~m}$ & & - & - & & & 0 & 0 & 0 \\
\hline 0. dentipes form $\mathrm{A}$ & M & & & & & & & \\
\hline $0-100 \mathrm{~m}$ & & 130 & 110 & 290 & 480 & 59 & 68 & 130 \\
\hline $100-250 \mathrm{~m}$ & & 32 & - & 65 & $710^{a}$ & 110 & 350 & 430 \\
\hline $250-450 \mathrm{~m}$ & & - & - & & & 0 & 8 & 0 \\
\hline $450-1050 \mathrm{~m}$ & & - & - & & & $1^{b}$ & 8 & 0 \\
\hline O. ivlevi & FM & & & & & & & \\
\hline $0-100 \mathrm{~m}$ & & 1400 & 1900 & 2200 & 3500 & 2400 & 7900 & 5600 \\
\hline $100-250 \mathrm{~m}$ & & 260 & - & 260 & $4000^{a}$ & 170 & 3000 & 3300 \\
\hline $250-450 \mathrm{~m}$ & & - & - & & & 24 & 48 & 8 \\
\hline $450-1050 \mathrm{~m}$ & & - & - & & & $10^{b}$ & 170 & 24 \\
\hline O. ivlevi/sp. K & FM & & & & & & & \\
\hline $0-100 \mathrm{~m}$ & & 130 & 0 & 540 & 0 & 0 & 0 & 0 \\
\hline $100-250 \mathrm{~m}$ & & 130 & - & 1900 & 0 & 0 & 0 & 0 \\
\hline $250-450 \mathrm{~m}$ & & - & - & & & 0 & 0 & 0 \\
\hline $450-1050 \mathrm{~m}$ & & - & - & & & 0 & 0 & 0 \\
\hline Oncaea sp. K & FM & & & & & & & \\
\hline $0-100 \mathrm{~m}$ & & 0 & 48 & 65 & 935 & 64 & 64 & 64 \\
\hline $100-250 \mathrm{~m}$ & & 3300 & - & 370 & $1500^{a}$ & 4100 & 510 & 820 \\
\hline $250-450 \mathrm{~m}$ & & - & - & & & 6050 & 1700 & 2200 \\
\hline $450-1050 \mathrm{~m}$ & & - & - & & & $2350^{b}$ & 40 & 170 \\
\hline O. media f. minor & $F M$ & & & & & & & \\
\hline $0-100 \mathrm{~m}$ & & 850 & 770 & 300 & 380 & 5000 & 2800 & 2000 \\
\hline $100-250 \mathrm{~m}$ & & 160 & - & 330 & $620^{\circ}$ & 81 & 220 & 380 \\
\hline $250-450 \mathrm{~m}$ & & - & - & & & 91 & 350 & 620 \\
\hline $450-1050 \mathrm{~m}$ & & - & - & & & $7^{b}$ & 28 & 130 \\
\hline O. subtilis & $\mathrm{F}$ & & & & & & & \\
\hline $0-100 \mathrm{~m}$ & & 2700 & 2800 & 3150 & 84 & 1 & 0 & 0 \\
\hline $100-250 \mathrm{~m}$ & & 320 & - & 130 & $360^{\circ}$ & 0 & 0 & 0 \\
\hline $250-450 \mathrm{~m}$ & & - & - & & & 0 & 0 & 0 \\
\hline $450-1050 \mathrm{~m}$ & & - & - & & & 0 & 0 & 0 \\
\hline O. subtilis/dentipes form B & $M$ & & & & & & & \\
\hline $0-100 \mathrm{~m}$ & & 3450 & 4900 & 4800 & 1350 & 5 & 0 & 0 \\
\hline $100-250 \mathrm{~m}$ & & 4200 & - & 180 & $1100^{d}$ & 0 & 0 & 0 \\
\hline $250-450 \mathrm{~m}$ & & - & - & & & 0 & 0 & 0 \\
\hline $450-1050 \mathrm{~m}$ & & - & - & & & 0 & 0 & 0 \\
\hline O. tregoubovi & FM & & & & & & & \\
\hline $0-100 \mathrm{~m}$ & & 130 & 0 & 1 & 0 & 64 & 0 & 130 \\
\hline $100-250 \mathrm{~m}$ & & 450 & - & 16 & $48^{\mathrm{a}}$ & 1600 & 130 & 80 \\
\hline $250-450 \mathrm{~m}$ & & - & - & & & 8700 & 1500 & 2400 \\
\hline $450-1050 \mathrm{~m}$ & & - & - & & & $8400^{b}$ & 3800 & 3600 \\
\hline
\end{tabular}


Table 8 (continued)

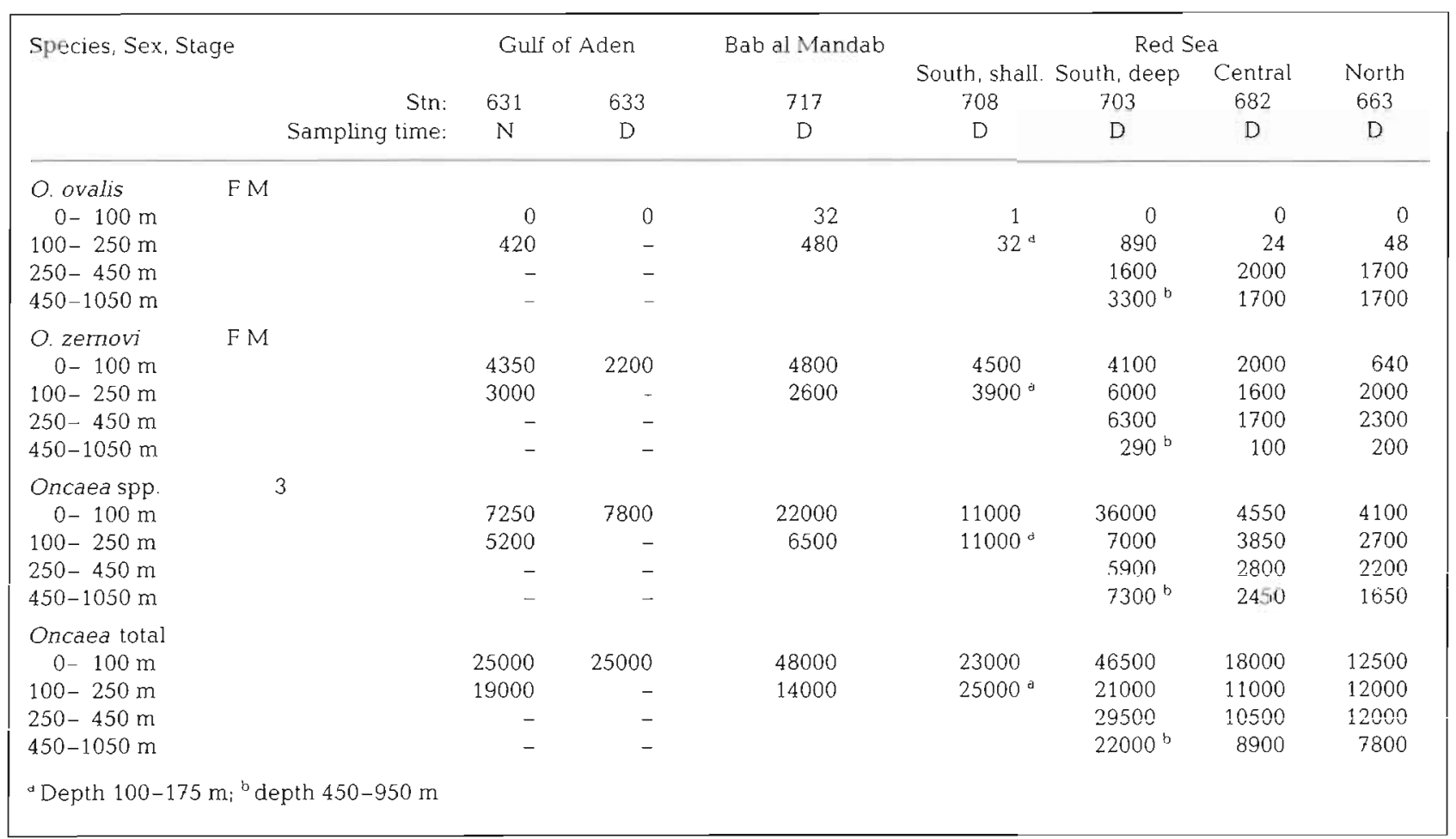

group. Among poecilostomatoids, the relative importance of Oncaea ivlevi is increased considerably in this area, with a share of 30 to $40 \%$ of the total number in this group. O. zernovi, O. media f. minor, and $O$. dentipes (form A) had relative abundances between 1 to $10 \%$ of the total. In this area, 2 Farranula species, $F$. carinata and F. rostrata, were also of some numerical importance (not mentioned in Table 8), each contributing 1 to $5 \%$ to the total number of poecilostomatoids.

Compared to these results from the epipelagic zone, regional differences were less pronounced in the deeper layers. The following 3 depth zones can be distinguished below $100 \mathrm{~m}$ with regard to the noncalanoid fauna.

Upper mesopeplagic zone (a) $\mathrm{O}_{2}$ gradient (100-250 m). The cyclopoid community of this zone was dominated by Paroithona spp. at all oceanic sites in the Red Sea and Gulf of Aden (Table 7). In the shallow waters of the southern Red Sea and at Bab al Mandab the dominance of this species was less pronounced. Among poecilostomatoids, the proportions of Oncaea zernovi and Oncaea sp. K increased compared to those in the upper $100 \mathrm{~m}$, while those of $O$. ivlevi and $O$. media f. minor were generally lower (Table 8). Regional differences in the composition of the dominant Oncaea species were generally similar to those in the upper $100 \mathrm{~m}$. The mormonilloids were mainly confined to this depth zone. The finer vertical resolution of samples at
Bab al Mandab showed that adult and juvenile Mormonilla minor were concentrated mainly at 80 to $150 \mathrm{~m}$ depth, in the cooler and less saline water flowing in from the Gulf of Aden (cf. Fig. 2).

Upper mesopelagic zone (b) $\mathrm{O}_{2}$ minimum (250-450 m). Below $250 \mathrm{~m}$ depth, Oncaea was the dominant genus within the copepod community (see Table 4). Compared to the 2 zones above, the species composition of Oncaea changed considerably. Dominant forms were Oncaea sp. K, O. ovalis, O. tregoubovi and O. zernovi, each sharing between 15 and $30 \%$ of the total poecilostomatoids at the 3 stations investigated. A south-tonorth decrease in the proportion of the 2 dominant species, $O$. tregoubovi and $O$. ovalis, was indicated (Table 8 ), but remains uncertain due to the limited data set in the southern Red Sea.

Lower mesopelagic/upper bathypelagic zone (450$1050 \mathrm{~m}$ ). In this depth zone, Oncaea tregoubovi always was the dominant species, amounting to ca $40 \%$ of all poecilostomatoids (Table 8). 0 . ovalis ranked second with percentages between 15 and $20 \%$ of the total. Oncaea sp. K contributed a considerable percentage $(10 \%)$ to all poecilostomatoids only in the southern Red Sea. Another 2 Oncaea species, $O$. conifera and $O$. hawii (not mentioned in Table 8), accounted for slightly over $1 \%$ of all poecilostomatoids in this depth layer in the centralnorthern Red Sea. 


\section{DISCUSSION}

\section{Hydrographic conditions during summer 1987}

At the southern entrance of the Red Sea, the hydrographic regime during the southwest monsoon period is usually characterized by an outflow of surface and deep water through the Strait of Bab al Mandab, which is compensated for by an inflow of Gulf of Aden surface water at an intermediate depth (Morcos 1970, Maillard \& Soliman 1986, Edwards 1987). Under these conditions the number of invading plankton species has been found to be minimal (Halim 1969, Weikert 1987). During summer 1987, however, the hydrographic condition was not typical for the season: rather, the current meter readings pointed to an inflow of stratified Gulf water at the surface, which was compensated for by an outflow of Red Sea water at greater depth (E. Mittelstaedt pers. comm.; see also Weikert $1988 b)$. This situation is typical for the northwest monsoon period, which prevails during the greatest part of the year (Morcos 1970, Edwards 1987). Thus, the observed south-to-north differences found in the species spectrum of non-calanoid copepods during the present study are not assumed to reflect minimal (summer) values, but can be viewed as a more typical feature found during the greatest part of the year.

\section{Horizontal distribution of epipelagic plankton}

Within the central-northern Red Sea, latitudinal differences in the environmental conditions were considerable during summer 1987, showing a south-to-north increase in salinity from 38.5 to $39.5 \mathrm{ppt}$. However no corresponding differences were found in total plankton biomass and/or metazoan abundance within. this region. This observation seems to contrast with many others which have indicated lower biomass and abundance values in the northern Red Sea $\left(22^{\circ}\right.$ to $\left.25^{\circ} \mathrm{N}\right)$ as compared to the central region (Delalo 1966, Ponomareva 1968, Gordeyeva 1970, Kornilova \& Fedorina 1970. Weikert 1980, 1987, Böttger 1985, BöttgerSchnack 1990b, Schneider et al. 1991, 1994, Beckmann unpubl. data). The difference may be due to the restricted northern extension $\left(23^{\circ} 40^{\prime} \mathrm{N}\right)$ of plankton sampling during the present study, which does not include the entire less-productive northern parts.

Between the central-northern and the southern Red Sea, however, pronounced differences were found in biomass, metazoan abundance and composition of the $0.05 \mathrm{~mm}$ mesh net plankton. Generally, biomass and numerical abundance of total metazoans as well as the species numbers of non-calanoid copepods were greater in the southern as compared to the central- northern part. This corresponds to the general southnorth trend reported for biomass, abundance and diversity of larger mesozooplankton (Delalo 1966, Rudyakov \& Voronina 1967, Halim 1969, 1984, Kimor 1973, Weikert 1980, 1981, Beckmann 1984, Casanova 1985) and can be explained by the more hostile environmental conditions in the central and northern Red Sea, especially the increase in salinity (e.g Morcos 1970). In the epipelagic zone, the south-to-north decrease in the numerical abundance of total metazoans was much lower than the corresponding decrease in biomass. This discrepancy is partly due to differences in the taxonomic composition: anthozoan larvae and large gelatinous zooplankton taxa (siphonophores and medusae) occurred mainly in the southern Red Sea and in the Strait of Bab al Mandab. They contributed a large proportion to the wet weight, but little to the total number of metazoans, which was dominated by small organisms $<0.4 \mathrm{~mm}$ in size. The exceptionally high biomass values at Bab al Mandab co-occurred moreover with a high phytoplankton standing stock and primary production, which was twice as high in the Strait as compared to the adjacent areas (A. Moigis in Weikert 1988b).

Latitudinal differences in species numbers were not consistent for all non-calanoid copepod genera investigated, however. Within the genera Oithona, Corycaeus, Sapphirina and Copilia, species numbers showed a relatively strong decrease to the north, even though not all species in the first 2 genera have been identified yet. The generally high numbers of Oncaea species, on the other hand, decreased only slightly to the north. Out of 12 epipelagic Oncaea species, only 2 (O. subtilis and Oncaea sp. AD) were absent in the central-northern Red Sea. However, within Oncaea species and also Oithona species a number of form or size variants were found in the southern Red Sea, which were rare or absent in the central area. Since most of the Oncaea variants have not yet been described in the literature, their taxonomic status has yet to be ascertained. A recent re-examination of a form variant of $O$. hawil from the southern Red Sea, for instance, indicated that this form should be regarded as a separate species (G. A. Boxshall pers. comm.). Also, the taxonomic status of $O$. tregoubovifrom the Gulf of Aden has to be clarified; in the adjacent Arabian Sea, a morphologically very similar species was found in high abundances in the epipelagic zone (Böttger-Schnack 1994). This has not been identified from the Red Sea yet, but may well be present in the Gulf. A more detailed taxonomic description of all small Oncaea species from the Red Sea is in progress in order to overcome difficulties in species identification and resulting problems in the ecological interpretation of data on species distribution. 
Of the 16 non-calanoid species or taxa restricted to the southern Red Sea and Gulf of Aden during the present summer survey (see Table 5), 10 have not been recorded from the central or northern areas during earlier investigations including different seasons (Delalo 1966, Halim 1969, Böttger-Schnack 1988, 1990b). Thus, they can be regarded as strictly southern species, which are transported from the Gulf of Aden into the southern Red Sea, but cannot survive in the extreme environment further north. Among the Poecilostomatoida, typical southern species were Oncaea subtilis, which dominated the southern fauna numerically, and Urocorycaeus furcifer, which was conspicuous due to is large size. Both species are not mentioned in previous records from the southern Red Sea (Delalo 1966, Halim 1969). However, U. furcifer is widespread in the Indian Ocean with particularly high abundances in the Gulf of Aden (Meenakshikunjamma 1974) and $O$. subtilis has recently been found in the Arabian Sea (Böttger-Schnack 1994). A further species, Mormonilla minor, is also assumed to belong to this group, although it was recorded from the central and northern Red Sea by Delalo (1966). However, all recent studies of larger and smaller mesozooplankton in the central and northern Red Sea (Weikert 1980, 1981, 1987 , Beckmann 1984, unpubl. data, Böttger 1985) have confirmed the year-round absence of this species in the central Red Sea.

In relation to the total number of 75 species or taxa of non-calanoid copepods investigated in the Red Sea, the number of 11 species restricted to the south appears to be comparably low. For chaetognaths, 7 out of 17 species recorded from the Red Sea have been found in the southern area only (J.-P. Casanova 1985, 1990 ) and for tintinnids 31 out of 108 species are restricted to this area (Halim 1969). A similar ratio was also found for the species numbers of calanoid copepods (Halim 1969, Kornilova \& Fedorina 1970), thecosome pteropods (Rampal 1988, 1990) and euphausiids (B. Casanova 1990). On the basis of the present taxonomic knowledge, this comparison indicates that noncalanoid copepod species as compared to other zooplankton groups are to a larger part less sensitive to the strong horizontal gradients in environmental conditions observed in the Red Sea.

Four species or forms that had previously been recorded from the northern-central area during winter were not found during summer 1987 in this area: Dioithona rigida, Oncaea venusta f. typica, Sapphirina ovatolanceolata-gemma, and Euterpina acutifrons. These species may have been transported further north into the Red Sea due to the stronger inflow in the latter period. The difference in the occurrence of $O$. venusta f. typica was most conspicuous. Thus, the indicator function of this species for the extension of the inflow from the Gulf of Aden as assumed by Böttger-Schnack (1990b) can be confirmed by the present data.

In contrast to the general south-north decrease in plankton abundances within the Red Sea, several poecilostomatoid species showed an increase from south to north, such as female Oncaea dentipes form A, O. ivlevi, Agetus limbatus, and Lubbockia squillimana. The numerical increase was most conspicuous for Lubbockia species, which were totally absent in samples from the Gulf of Aden $(0-250 \mathrm{~m})$. As Lubbockia species inhabit the epi- and also the mesopelagic zone in the Red Sea (Böttger-Schnack $1990 \mathrm{a}, \mathrm{b}$, this study), the limited vertical range of sampling in the Gulf may explain why none of these species were encountered in that area. However, several samples were additionally taken with a $0.1 \mathrm{~mm}$ mesh net from the underlying depth layer 200-500 $\mathrm{m}$ in the Gulf of Aden during summer 1987 (C. Hemleben in Weikert 1988b). These samples contained only 1 single juvenile specimen of L. aculeata, thus confirming the general scarcity of Lubbockia in this area. Sampling with $0.3 \mathrm{~mm}$ mesh nets during different seasons confirmed a general decrease in abundance for the genus Lubbockia from the central Red Sea to the Gulf of Aden (W. Beckmann unpubl.). L. aculeata and $L$. squillimana have a widespread distribution in the Indian Ocean (Stephen 1988) and their virtual absence in the Gulf of Aden is quite unexpected. Based on this observation, Lubbockia species in the Red Sea seem to represent isolated local populations, which are independent of a regular recruitment from the Gulf of Aden. This phenomenon has already been pointed out for several other zooplankton species, such as Haloptilus longicornis among calanoid copepods (Beckmann 1984) or Sagitta pacifica among chaetognaths (Casanova 1985, 1986).

Oncaea ivlevi, also exhibiting a very strong numerical increase from south to north in the Red Sea, is again an epipelagic species of wider distribution in the Atlantic and the Mediterranean (Malt 1982, 1983), but has only rarely been quantitatively investigated due to its small size. In the Red Sea, it occurs mainly in the lower epipelagic zone, below the thermocline (BöttgerSchnack 1990a, b, this study). In the Arabian Sea, the typical $O$. ivlevi has not yet been found, but a closely related species, which is still unidentified, occurs in the epipelagic zone (Böttger-Schnack 1994). The presence of single exuviae of typical O. ivlevi in the central Arabian Sea (unpubl data) indicate that the species may be present during other seasons or in different regions of the Indian Ocean. More complete data on the geographical distribution of $O$. ivlevi are required from the Indian Ocean, in order to assess the origin of this numerically important small oncaeid in the Red Sea. 
Table 9. Seasonal differences in fine mesh net plankton biomass ig wet wt beneath $1 \mathrm{~m}^{2}$, excluding single large organisms; mean for day and night) and metazoan abundance and size composition (no. of ind. $\times 10^{3}$ beneath $1 \mathrm{~m}^{2}$, daytime values) in the upper $450 \mathrm{~m}$ of the central Red Sea. (n) no. of sampling series

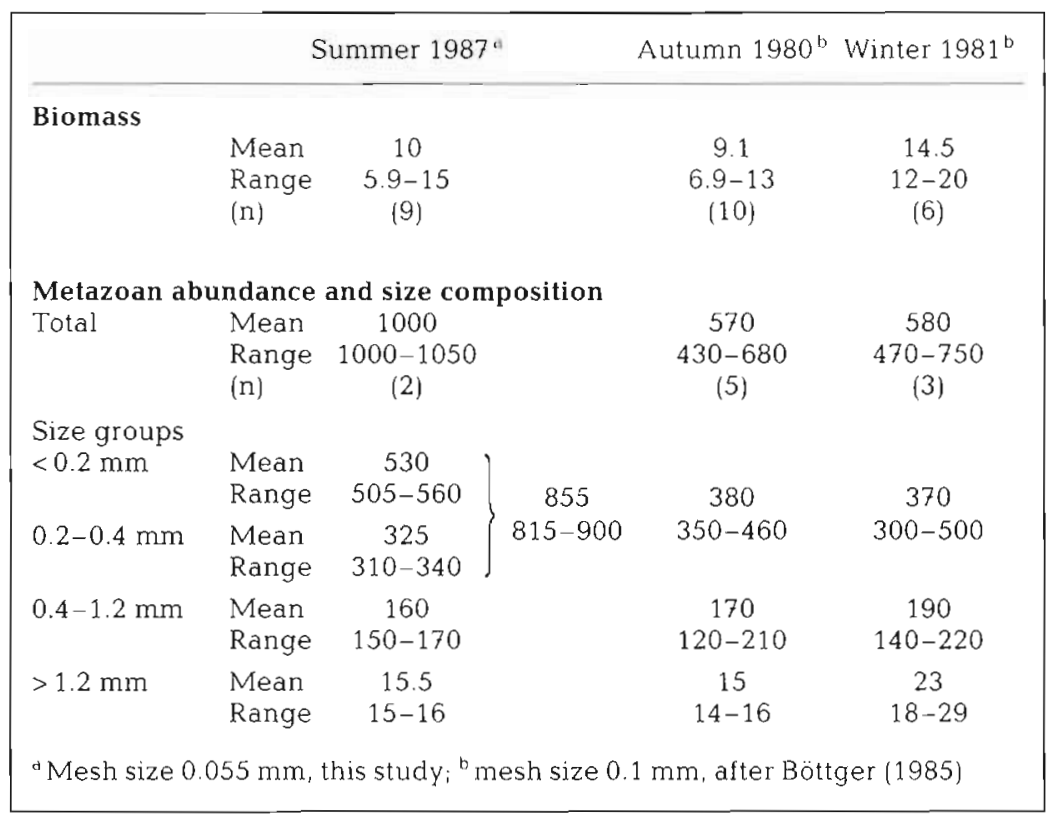

In the central Red Sea, seasonal variations in zooplankton abundance and composition are based on changes in primary production within this area but also on allochthonous influences from the southern Red Sea (Weikert 1987). This influence has been observed to be greatest during winter. An important indicator of southern inflow conditions has been found in the calanoid copepod Eucalanus spp., which occurs in its maximum abundance during winter and in low numbers during summer and autumn (Weikert 1980, 1987 , Beckmann 1984 and unpubl. data). A corresponding seasonal pattern has also been found for a few species of non-calanoid copepods (Table 10), among which Oncaea venusta f. typica is the most important one, due to its large size. Together with $O$. clevei and Oithona nana they are assumed to be allochthonous organisms from the southern Red Sea.

\section{Seasonal differences in the central Red Sea}

The total biomass of the fine mesh net plankton sampled in summer 1987 per standard area in the upper $450 \mathrm{~m}$ was similar to that obtained during earlier investigations in autumn 1980 (Böttger 1985, 1987), but significantly lower than that found during winter 1981 in the central Red Sea (Mann-Whitney $U$-test, $p<0.05$ ) (Table 9). The mesh size used during the earlier investigations was somewhat larger $(0.1 \mathrm{~mm})$ than during the present summer survey $(0.05 \mathrm{~mm})$. Thus, the summer value has to be taken as an overestimation in this comparison and may, in fact, be lowest. For the autumn, Gordeyeva (1970) (mesh size $0.06 \mathrm{~mm}$ ) reported much higher biomass values of $16 \mathrm{~g} \mathrm{~m}^{-2}$ in the upper $500 \mathrm{~m}$ of the central and northern Red Sea, but her data are not directly comparable to the present biomass (wet weight) values, because a different method of biomass determination was used ('Yashnovcounting-weight method'). The seasonal comparison may be more realistic for numerical abundance values (Table 9) rather than biomass, as numbers are given by size categories and may be restricted to the size fraction of organisms quantitatively sampled by both mesh sizes used. The numbers of organisms above $0.4 \mathrm{~mm}$ in size confirm the general picture obtained for biomass and they indicate that the high winter values are mainly due to on the larger size fraction above $1.2 \mathrm{~mm}$.
Table 10. Seasonal variation in the abundance of non-calanoid copepod species $>0.5 \mathrm{~mm}$ in size in the central Red Sea. Data from autumn and winter were derived from Böttger-Schnack $(1988,1990 a, b)$, summer values were taken from the present study. Species are listed in alphabetical order

Species showing maximum abundances during winter,

but low numbers during summer and/or autumn

$$
\begin{aligned}
& \text { Oithona nana } \\
& \text { Oncaea clevei } \\
& \text { O. venusta f. typica } \\
& \text { f. venella }
\end{aligned}
$$

Species showing maximum abundances during summer and/or autumn, but low numbers during winter

Corycaeus speciosus
Farranula carinata
F. rostrata
Oncaea conifera
O. rufa

Species showing no or no consistent seasonal variation Copilia mirabilis

Agetus limbatus

Lubbockia aculeata

L. squillimana

Oncaea dentipes form A

O. hawii

O. media f. minor

f. major

O. mediterranea

O. minuta

O. umerus

Sapphirina metallina

Vettoria parva 
In addition, 2 other groups of non-calanoids may be defined according to their seasonal pattern (Table 10):

(1) Species showing maximum abundances during summer and/or autumn, but low numbers during winter. This group includes 5 species (Table 10), of which the 3 corycaeid species are assumed to be independent in their population dynamics from southern inflow conditions, as they are found in the southern Red Sea in low abundances only (Table 5).

(2) Species exhibiting no or no consistent seasonal variation in abundance in the central Red Sea. This group includes the greatest number of species (Table 10). Most of them, in particular Oncaea dentipes form A, Lubbockia squillimana and Agetus limbatus, also do not seem to be substantially recruited from the southern Red Sea, as they were usually less abundant in that area (Table 5). Some exchange between the areas cannot be excluded for species within this group however (e.g. Oncaea media f. minor).

In summary, it can be stated that the non-calanoid fauna above $0.5 \mathrm{~mm}$ in size in the central Red Sea is mainly represented by local populations. Only a few southern species seem to have any substantial seasonal influence.

Acknowledgements. I thank Dr H. Weikert and his working team, who collected the plankton matenal in the Red Sea during the METEOR-5 expedition. Prof. C. Hemleben provided some deep plankton samples from the Gulf of Aden. Thanks are due to Prof. D. Schnack for continuous support and help during the study. He and Prof. J. Lenz and Dr G. A. Boxshall commented on the manuscript. Dr F. D. Ferrari verified the taxonomic identification of oithonid species and Dr R. Huys helped with the identification of some rare harpacticoids. Dr D. Quadfasel provided the hydrographic computations, and $M$. Ruth constructed the plankton graphics. Sincere thanks are given to Mrs U. Weber, who assisted in the plankton sorting. The constructive comments of 3 anonymous referees helped to improve the manuscript. This study was supported by Deutsche Forschungsgemeinschaft grant We $695 / 12$ to $H$. Weikert

\section{LITERATURE CITED}

Arthur, D. K. (1977). Distribution, size, and abundance of microcopepods in the California Current system and their possible influence on survival of marine teleost larvae. Fish. Bull. U.S. 75: 605-611

Beckmann, W. (1984). Mesozooplankton distribution on a transect from the Gulf of Aden to the central Red Sea during the winter monsoon. Oceanol. Acta 7: 87-102

Böttger, R. (1982). Studies on the small invertebrate plankton of the Sargasso Sea. Helgoländer Meeresunters. 35: $369-383$

Böttger, R. (1985). Untersuchungen zur Verteilung der kleinen Metazoa im Plankton des Roten Meeres, unter besonderer Berücksichtigung cyclopoider und harpacticoider Copepoden. Doctoral dissertation. Universität Hamburg

Böttger, R. (1987). The vertical distribution of micro- and small mesozooplankton in the central Red Sea. Biol. Oceanogr. 4: 383-402

Böttger-Schnack, R. (1988). Observations on the taxonomic composition and vertical distribution of cyclopoid copepods in the central Red Sea. In: Boxshall, G. A., Schminke, H. K. (eds.) Biology of copepods. Proc. 3rd int. Conf. on Copepoda, London, August 10-14, 1987. Hydrobiologia 167/168: $311-318$

Böttger-Schnack, R. (1990a). Community structure and vertical distribution of cyclopoid copepods in the Red Sea. I. Central Red Sea, autumn 1980. Mar. Biol. 106: 473-485

Böttger-Schnack, R. (1990b). Community structure and vertical distribution of cyclopoid copepods in the Red Sea. II. Aspects of seasonal and regional differences. Mar. Biol. 106: $487-501$

Böttger-Schnack, R. (1991). Seasonal changes in the vertical distribution and size structure of Macrosetella gracilis populations (Copepoda, Harpacticoida) in the Red Sea Bull. Plankton Soc. Jap. (Spec. vol.): 309-320

Böttger-Schnack, R. (1992). Community structure and vertical distribution of cyclopoid and poecilostomatoid copepods in the Red Sea. III Re-evaluation for separating a new species of Oncaea. Mar. Ecol. Prog. Ser. 80: 301-304

Böttger-Schnack, R. (1994). The microcopepod fauna in the Eastern Mediterranean and Arabian Seas: a comparison with the Red Sea fauna. Hydrobiologia 292/293: $271-282$

Böttger-Schnack, R., Schnack, D., Weikert, H. (1989). Biological observations on small cyclopoid copepods in the Red Sea. J. Plankton Res. 11. 1089-1101

Boxshall, G. A., Böttger-Schnack, R. (1988). Unusual ascothoracid nauplii from the Red Sea. Bull. Br. Mus. nat. Hist. (Zool.) 54: 275-283

Casanova, B. (1990). Biologie et biogéographie des euphausiacés de la mer Rouge. Relations avec les mers voisines. In: Godeaux, J. (ed.) A propos des migrations lessepsiennes. Bull. Inst. océanogr. Monaco, no. spéc. 7: 117-129

Casanova, J.-P. (1985). Les chaetognathes de la Mer Rouge. Remarques morphologiques et biogéographiques. Description de Sagitta erythraea sp.n. Rapp. P.-v. Réun. Commn int. Explor. scient. mer Méditerr. 29: 269-274

Casanova, J.-P. (1986). Similarity of plankton distribution patterns in two nearly land-locked seas: the Mediterranean and the Red Sea. In: Pierrot-BuIts, A. C., Van der Spoel, S., Zahuranec, B. J., Johnson, R. K. (eds.) Pelagic biogeography. Proceedings of an international Conference, The Netherlands, 29 May-5 June 1985. UNESCO Tech. Pap. mar. Sci. 49: $42-46$

Casanova, J.-P. (1990). Taxonomie et biogéographie des chaetognathes de la mer Rouge. Comparaison avec les mers voisines. In: Godeaux, J. (ed.) A propos des migrations lessepsiennes. Bull. Inst. océanogr Monaco, no spéc. $7: 89-102$

Cowles, T J., Roman, M. R., Gauzens, A. L., Copley, N. J (1987). Short-term changes in the biology of a warm-core ring: zooplankton biomass and grazing. Limnol. Oceanogr. 32: $653-664$

Delalo, E. P. (1966). Distribution of the zooplankton biomass in the Red Sea and the Gulf of Aden, winter 1961/62 Okeanol. issled. 15: 131-139 (in Russian)

Edwards, F. J. (1987). Climate and oceanography. In Edwards, A. J., Head, S. M. (eds.) Red Sea. Key environments. Pergamon Press, Oxford, p. 45-69

Ferrari, F. D., Böttger, R. (1986). Sexual dimorphism and a sex-limited polymorphism in the copepod Paroithona pacifica Nishida, 1985 (Cyclopoida: Oithonidae) from the Red Sea. Proc. Biol. Soc. Wash. 99(2): 274-285 
Gordeyeva, K. T. (1970). Quantitative distribution of zooplankton in the Red Sea. Okeanologiya 10:867-871

Govoni, J. J., Ortner, P. B., Al-Yamani, F., Hill, L. C. (1986) Selective feeding of spot, Leistomus xanthurus, and Atlantic croaker, Micropogonias undulatus, larvae in the northern Gulf of Mexico. Mar. Ecol. Prog. Ser. 28: 175-183

Grygier, M. J. (1987). New records, external and internal anatomy and systematic position of Hansen's y-larvae (Crustacea: Maxillopoda: Facetotecta). Sarsia 72: 261-276

Grygier, M. J. (1993). Late planktonic naupliar development of an ascothoracidan crustacean (? Petrarcidae) in the Red Sea and a comparison to the Cirripedia. Contr. Sci 437: $1-14$

Halim, Y (1969). Plankton of the Red Sea. Oceanogr mar. biol. A. Rev. 7: 231-275

Halim, Y. (1984). Plankton of the Red Sea and the Arabian Gulf. Deep Sea Res. 31: 969-982

Huys, R., Boxshall, G. A. (1991). Copepod evolution. The Ray Society, London

Huys, R., Böttger-Schnack, R. (in press). Taxonomy, biology and phylogeny of Miraciidae (Copepoda: Harpacticoida). Sarsia

Kellermann, A. (1990). Food and feeding dynamics of the larval Antarctic fish Nototheniops larseni. Mar. Biol. 106 $159-168$

Kimmerer, W. J. (1984). Selectlve predation and its impact on prey of Sagitta enflata (Chaetognatha). Mar Ecol. Prog Ser, 15: 55-62

Kimor, B. (1973). Plankton relations in the Red Sea, Persian Gulf and Arabian Sea. In: Zeitzschel, B., Gerlach, S. A. (eds.) The biology of the Indian Ocean, Ecological studies 3. Springer-Verlag, Heidelberg, p. 221-232

Kinzer, J., Böttger-Schnack, R., Schulz, K. (1993). Aspects of horizontal distribution and diet of myctophid fish in the Arabian Sea with reference to the deep water oxygen deficiency. Deep Sea Res. II. 40 (3): 783--800

Kornilova, G. N., Fedorina, A. I. (1970). The zooplankton of the Red Sea. Tr. Azovo-Chernomorsk. Nauchno-Issled. Inst. Morsk. Rybn. Khoz. Okeanogr. 30: 48-59 (in Russian)

Maillard, C., Soliman, G. F. (1986). Hydrography in the Red Sea and exchanges with the Indian Ocean in summer Oceanol. Acta 9: 249-269

Malt, S. J. (1982). New and little known species of Oncaeidae (Cyclopoida) from the Northeastern Atlantic. Bull. Br. Mus. nat. Hist. (Zool.) 42: 185-205

Malt. S. J. (1983). Studies on the taxonomy and ecology of the marine copepod genus Oncaea Philippi. Ph.D. thesis, University of London

Meenakshikunjamma, P. P. (1974). The distribution of the subgenus Urocorycaeus (Genus Corycaeus, Corycaeidae, Copepoda) in the Indian Ocean. J. mar. biol. Ass. India 16: 769-774

Metz, C. (1993). Verbreitung von Cyclopoida (Copepoda, Crustacea) im Weddellmeer. Diploma thesis, University of Kiel

Morales, C. E., Bedo, A., Harris, R. P., Tranter, P. R. G. (1991) Grazing of copepod assemblages in the north-east Atlantic: the importance of the small size fraction. J. Plankton Res. 13: 445-472

Morales, C. E., Harris, R. P., Head, R. N., Tranter, P. R. G (1993). Copepod grazing in the oceanic northeast Atlantic during a 6 week drifting station: the contribution of size classes and vertical migrants. J. Plankton Res. 15 $185-211$

Morcos, S. A. (1970). Physical and chemical oceanography of the Red Sea. Oceanogr. Mar. Biol. A. Rev. 8: 73-202

Ponomareva, L. A. (1968). Quantitative distribution of zoo- plankton in the Red. Sea as observed in the period May-June 1966. Oceanology 8: 240-242

Rampal, J. (1988). Les thécosomes de la mer Rouge. Rapp. P.-v. Réun. Commn int. Explor. scient. mer Méditerr 31. 300

Rampal, J. (1990). Les thécosomes de la mer Rouge. In Godeaux, J. (ed.) A propos des migrations lessepsiennes. Bull. Inst. océanogr. Monaco, no. spéc. 7. 103-107

Roman, M. R., Gauzens, A. L., Cowles, T. J (1985). Temporal and spatial changes in epipelagic microzooplankton and mesozooplankton biomass in warm-core Gulf Stream ring 82-B. Deep Sea Res. 32: 1007-1022

Rudyakov, Y A., Voronina, N. M. (1967). Plankton and bioluminescence in the Red Sea and Gulf of Aden. Okeanologiya 6: 838-848

Schnack, S. B., Marschall, S., Mizdalski, E. (1985). On the distribution of copepods and larvae of Euphausia superba in the Antarctic waters during February 1982. Meeresforsch Rep. mar. Res. 30: 251-263

Schneider, G., Lenz, J., Rolke, M. (1991). Zum Bestand und Stoffumsatz des Ultra-, Mikro- und Mesozooplanktons im Roten Meer und im Golf von Aden. Ber. Inst. Meeresk. Kiel 205: 1-167

Schneider, G., Lenz, J., Rolke, M. (1994). Zooplankton standing stock and community structure within the epipelagic zone: a comparison between the central Red Sea and the Gulf of Aden. Mar. Biol. 115: 191-193

Siedler, G. (1968). Schichtungs- und Bewegungsverhältnisse am Südausgang des Roten Meeres. 'Meteor' Forsch. Ergebn. (A) 4: 1-76

Star, J. L., Mullin, M. M. (1981). Zooplankton assemblages in three areas of the North Pacific as revealed by continuous horizontal transects. Deep Sea Res. 28A(11): 1303-1322

Steedman, H. F. (1976). Examination, sorting and observation fluids. In: Steedman, H. F. (ed.) Zooplankton fixation and preservation. Monographs on oceanographic methodology, Vol. 4. UNESCO Press, Paris, p. 182-183

Stephen, R. (1988). Oncaeidae (Copepoda: Poecilostomatoida) in the lndian Ocean with comments on the species of Lubbockla and Conaea. Mahasagar 21: 35-44

Verch, N., Ungewiß, M., Schulze, K., Quadfasel, D. (1989a). MINDIK 1987 - RV METEOR Cruise 5. CTD observations in the Red Sea and the Gulf of Aden. Tech. Rep. Inst. Meeresk. Univ. Hamburg 1-89: 1-16

Verch, N., Petzold, M., Mahnke, P., Quadfasel, D. (1989b) Hydrographic bottle data obtained in the Red Sea and Gulf of Aden during RV METEOR Cruise 5 - MINDIK 1987 Tech. Rep. Inst. Meeresk. Univ. Hamburg 2-89: 1-16

Weikert, H. (1977). Copepod carcasses in the upwelling region south of Cap Blanc, N.W. Africa. Mar Biol. 42 351-355

Weikert, H. (1980). On the plankton of the central Red Sea. A first synopsis of results obtained from the cruises MESEDA I and MESEDA II. Proc. Symp. coast. mar. environ. Red Sea, Gulf Aden and tropical western Indian Ocean Khartoum, January 9-14, 1980. The Red Sea and Gulf of Aden Environmental programme, Jeddah, p. 135-167

Weikert, H. (1981). The pelagic communities. In: Karbe, L. Thiel, H., Weikert, H., Mill, A. J. B. (eds.) Mining of metalliferous sediments from the Atlantis II Deep, Red Sea: premining environmental conditions and evaluation of the risk to the environment. Environmental impact study presented to the Saudi-Sudanese Red Sea Joint Commission Jeddah, p. 100-154

Weikert, $\mathrm{H}$. (1982). The vertical distribution of zooplankton in relation to habitat zones in the area of the Atlantis II Deep. central Red Sea. Mar. Ecol. Prog. Ser. 8: 129-143 
Weikert, H. (1987). Plankton and the pelagic environment. In: Edwards, A. J., Head, S. M. (eds.) Red Sea, Key environments. Pergamon Press, Oxford, p. 90-111

Weikert, H. (1988a). New information on the productivity of the deep Eastern Mediterranean and Red Seas. Rapp. P.-v. Réun. Comm. int. Explor. scient Mer Méditerr. 31: 305

Weikert, H. (ed.) (1988b). Expeditionsbericht über die METEOR-Reise 5 Abschnitt 5. (3. Juli bis 16. August 1987.

This article was submitted to the editor
Rotes Meer/Mombasa - Port Sudan - Hudaydah - Heraklion). Berichte aus dem Zentrum für Meeres- und Klimaforschung der Universität Hamburg, Hamburg

Weikert, H., John, H.-C. (1981). Experiences with a modified Bé multiple opening-closing plankton net. J. Plankton. Res. 3: 167-176

Wheeler, E. H. Jr (1967). Copepod detritus in the deep sea. Limnol. Oceanogr. 12: 697-702

Manuscript first received: October 5, 1993

Revised version accepted: November 22, 1994 